\title{
Relatos de campanha: a expansão colonial portuguesa sobre os quilombos do Alto São Francisco e Alto Paranaíba no século XVIII'
}

Stories of a campaign: Portuguese territorial expansion into the quilombos of Alto São Francisco and Alto Paranaíba Rivers in the 18th century

https://doi.org/10.1590/1982-0267202 lv29dle24

\section{KAREN PESSOA FREIRE ${ }^{2}$}

https://orcid.org/0000-000 1-8549-7148

Universidade de São Paulo / São Paulo, SP, Brasil

RESUMO: Abrigando um expressivo número de quilombos ao longo do século XVIII, a zona entre os rios Grande, São Francisco e Paranaíba era conhecida como sertão do Campo Grande, tendo em seu entorno importantes núcleos de exploração mineradora e agropecuária das capitanias de Goiás, Minas Gerais e São Paulo. Com o objetivo de dilatar seus domínios, - Estado português organizou campanhas militares para conquistar esse planalto fértil habitado por quilombolas e ameríndios inimigos. Neste artigo abordamos a expedição liderada por Ignacio Correya Pamplona em 1769, analisando as estratégias usadas por essa campanha para a expansão territorial luso-americana por meio do combate aos quilombolas e da apropriação de suas terras. Para isso, examinamos um conjunto de documentos produzidos pelos próprios expedicionários que conta com relatos escritos, desenhos do interior de quilombos e um mapa da região explorada. Na análise documental e na tradução do mapa sertanista para a cartografia recente, verificamos que os quilombos destruídos (que possuíam roças, pilões, manufaturas e diversificadas organizações sociopolíticas) foram usados como base para o estabelecimento da estrutura colonial luso-americana, por meio da instalação de estradas, ranchos para descanso e abastecimento de tropas, demarcação de fazendas e povoados destinados aos súditos da coroa Bragança. $\bigcirc$ estudo desse episódio da guerra entre quilombolas e luso-americanos revela que, involuntariamente, tais quilombos foram elementos pioneiros na formação da malha territorial nessa região que atualmente integra o Triângulo Mineiro.

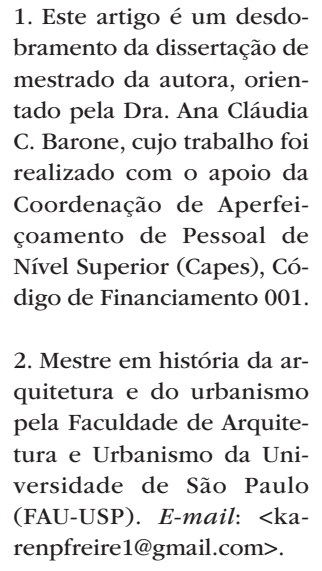

1. Este artigo é um desdobramento da dissertação de mestrado da autora, orientado pela Dra. Ana Cláudia C. Barone, cujo trabalho foi realizado com o apoio da Coordenação de Aperfeiçoamento de Pessoal de Nível Superior (Capes), Código de Financiamento 001.

2. Mestre em história da arquitetura e do urbanismo pela Faculdade de Arquitetura e Urbanismo da Universidade de São Paulo (FAU-USP). E-mail: <karenpfreire1@gmail.com>. 
PALAVRAS-CHAVE: Quilombos. Expansão territorial portuguesa no século XVIII. Povoamento do Triângulo Mineiro. Alto São Francisco e Paranaíba. Sertão do Campo Grande. Cartografia histórica.

ABSTRACT: The area between Grande, São Francisco, and Paranaíba Rivers was known as Sertão of Campo Grande. It was home to a significant number of quilombos throughout the 18th century, and surrounded by important gold mining and farming centers of the captaincies of Goiás, Minas Gerais, and São Paulo. Aiming at expanding its domains, the Portuguese Crown organized military campaigns to conquer that fertile plateau inhabited by its enemies quilombolas and Amerindians. In this paper, we will address these expeditions, namely the one led by Ignacio Correya Pamplona in 1769, analyzing the strategies used by the campaign aimed at the Luso-American territorial expansion through fighting the quilombolas and appropriating their lands. For such purpose, we examine a set of documents executed by the expedition members themselves, which include written reports, drawings depicting the inside of the quilombos, and a map of the region explored. After analyzing these documents and translating the colonial map into recent cartography, we verified that the quilombos destroyed (which had vegetable plots, pestles, manufacturing activities, diverse social-political organizations) were used as the basis to establish the Luso-American colonial structure by the construction of roads, ranches for troops to rest and find supply, demarcation of farms and villages for the subjects of the Bragança Crown. Studying this episode of the war between quilombolas and Luso-Americans shows that, involuntarily, the aforementioned quilombos were pioneer elements for the formation of the territorial network in the area that today is part of the Triângulo Mineiro.

KEYWORDS: Quilombos. Portuguese territorial expansion in the 18th century. Settlement in the Triângulo Mineiro. Alto São Francisco and Paranaíba Rivers. Sertão of Campo Grande. Historic cartography. 


\section{INTRODUÇÃO}

No alvorecer do século XVIII, o território americano sob domínio português era fragmentado, restrito a manchas de povoamento fronteiriças a espaços inacessíveis aos luso-americanos, pois eram habitados por quilombolas e ameríndios hostis. Sem a organização direta do Estado colonial, as incursões ao interior ficavam a cargo de aventureiros que não se fixavam nas terras exploradas. ${ }^{3} \bigcirc$ reduzido conhecimento dos lusitanos sobre o interior da América é visível em sua cartografia histórica. Diferentemente das cartas de marear quinhentistas, restritas ao litoral, os mapas do século XVII apresentam algumas informações sobre a distribuição de povos indígenas e sobre os caminhos terrestres e fluviais para os sertões descobertos por missionários religiosos ou sertanistas. No entanto, nessas cartas ainda era exíguo o detalhamento das terras afastadas da costa. ${ }^{4}$

$\bigcirc$ interesse português pela exploração do interior do continente foi despertado somente nos últimos anos do século XVII, quando foram descobertas jazidas de minerais preciosos (algumas localizadas além do limite fixado pelo Tratado de Tordesilhas). Disputando o domínio das terras americanas com indígenas, quilombolas e espanhóis, o processo lusitano de expansão territorial ao longo do século XVIII envolveu acordos diplomáticos, organização de expedições de conquista dos sertões e o desenvolvimento de documentos cartográficos que permitissem administrar e explorar os espaços. ${ }^{5}$

Com o acordo de paz de Utrecht, de 1713, que invalidou o Tratado de Tordesilhas, a soberania sobre as terras passou a depender de sua ocupação efetiva. Assim, foram adotadas diferentes estratégias para ampliar e defender o patrimônio ultramarino da coroa de Bragança. ${ }^{6} \mathrm{Na}$ década de 1750, com o Tratado de Madri e a ascensão do marquês de Pombal a primeiro-ministro, povoar as zonas de fronteiras com súditos portugueses (mesmo que fossem índios aldeados, mestiços ou ilhéus do arquipélago dos Açores) passou a ser uma das prioridades da administração metropolitana.?

Dessa maneira, a partir de meados do Setecentos, o Estado colonial assumiu a coordenação de expedições de conquista e ocupação em diferentes partes do continente, convocando seus súditos a financiarem e participarem das entradas para os sertões, ampliando os limites de suas fronteiras territoriais por meio do combate a indígenas e quilombolas. Conforme prática do Antigo Regime, os vassalos que empregavam seus recursos materiais e esforços pessoais em massacrar os adversários religiosos e culturais de sua majestade podiam receber como remuneração cargos administrativos, títulos honoríficos e a concessão de terras. ${ }^{8}$
3. Santos (2010, p. 17-32, 146-150, 308-333).

4. Costa (2007, p. 95-98).

5. Ibid., p. 83-223; Kantor (2009, p. 39-61); Santos, op. cit., p. 34-88.

6. Kantor, op. cit., p. 39-61.

7. Souza (1999, p. 114).

8. Ibid., p. 111-137; Santos, op. cit., p. 146-150. 
9. A elaboração da cartografia científica teve início na França nos anos 1720 . Os trabalhos de mapeamento técnico na América portuguesa foram iniciados a partir da década de 1730 . No entanto, devido à escassez numérica de técnicos e instrumentos e às dificuldades de adentrar o continente, a primeira Carta Geral com latitude e longitude foi finalizada somente em 1798 (GUEDES, 2007, p. 19-27).

10. Bueno (2007, p. 29-49); Costa, op. cit., p. 95-98.

11. Ab'Sáber (2003, p. 1131); Ross (2005, p. 32-65).

12. Resende (2007, p. 25-53); Fonseca (2011. p. 25-81).

13. Venâncio (2007, p. 87102).
Anônimos nos documentos que produziam, certos expedicionários eram encarregados de elaborar relatórios e esboços cartográficos que apresentavam para as autoridades coloniais os locais explorados. Contando com escassos recursos técnicos, ${ }^{9}$ essas rústicas "cartas sertanistas" e os relatos de campo permitiam que os combatentes cobrassem contrapartidas pelos serviços de conquista prestados à Coroa, ao mesmo tempo que serviam ao Estado português como meio de conhecer os espaços. Tais retratos do Império forneciam elementos para compor documentos destinados à reivindicação, perante as autoridades europeias, de posse das áreas ocupadas, assim como eram instrumentos essenciais para o controle administrativo colonial. ${ }^{10}$ Por isso, as áreas de especial interesse para os luso-americanos foram amplamente retratadas nesses documentos, como é o caso da zona em processo de conquista no Campo Grande.

Podemos compreender um pouco da cronologia da ocupação do Campo Grande por meio de trabalhos de pesquisadores que, a partir de documentos oficiais da administração portuguesa, analisaram os processos de povoamento e as disputas entre agentes lusitanos, quilombolas e indígenas pelo domínio dessa zona.

Integrando o que hoje chamamos de Triângulo Mineiro e suas adjacências, a vasta região conhecida no século XVIII como sertão do Campo Grande fica em zona de planalto intertropical, apresentando solo fértil e densa rede hidrográfica perene, " englobando parte da bacia do rio Grande e abrigando as nascentes dos rios Paranaíba e São Francisco (nomes atuais). O Campo Grande era uma zona de fronteira entre as capitanias de Goiás, Minas Gerais e São Paulo e estava fora do domínio efetivo delas. Os limites desse sertão eram mal definidos, uma vez que era pouco conhecido pelos luso-americanos. A região era vizinha de áreas de exploração aurífera a leste, na serra do Espinhaço (onde ficava o distrito diamantino, a cidade de Mariana, vila Rica e vila do Sabará, entre outras); ao sul em alguns trechos da bacia do rio Grande; e ao norte, junto ao rio Paracatu, entre outras. ${ }^{12}$ Naquele momento o Campo Grande era povoado por indígenas e quilombolas.

Entre os habitantes mais antigos do Campo Grande estavam os indígenas Tremembé, conhecidos ali por Cataguá ou Araxá, que se instalaram entre os rios Quebra-Anzol e das Velhas (atual Araguari). No século XVII, com a migração de indígenas Kayapó para a região, os dois grupos entraram em conflito pelo domínio desses espaços, cujo resultado foi o predomínio dos Kayapó. Essas áreas sofriam ataques de bandeirantes para captura de índios llevados como escravizados para outras regiões) e, nos últimos anos do século XVII, a região passou a ser visada pelos súditos portugueses para a agropecuária, mas as ações guerreiras dos Kayapó impediam que esses luso-americanos se estabelecessem. ${ }^{13}$ 
O domínio dos índios Kayapó no Campo Grande foi combatido pelos luso-americanos por pelo menos meio século. Sob a liderança de um agente português, empreendeu-se em 1739 um ataque de índios Bororó contra os Kayapó, fixando-se na região um quartel-aldeamento para servir de base aos luso-americanos. Em 1782, foi comandada por Ignacio Pamplona outra expedição de combate aos ameríndios da região. ${ }^{14}$

De acordo com documentos oficiais do Estado português, os quilombos existiam no sertão do Campo Grande pelo menos desde a década de 1720. ${ }^{15}$ É possível, no entanto, que o estabelecimento de quilombolas nessa zona fosse anterior. No entanto, não restaram documentos para confirmar datas mais precisas, a não ser os de seus algozes.

Otermo "Quilombo" era usado nos documentos públicos da administração portuguesa na região das minas auríferas setecentistas para se referir aos ajuntamentos de fugitivos. ${ }^{16}$ Desde a década de 1740, os ajuntamentos que não estivessem subordinados ao Estado português poderiam ser considerados quilombos, quer fossem constituídos por um pequeno grupo de fugitivos sem "roças" e "pilões", quer fossem povoados com centenas de pessoas e dotados de organizações sociopolíticas e econômicas próprias. Considerados ilegais, esses povoados podiam sofrer ataques de agentes lusitanos. Visto que nas regiões auríferas vizinhas predominava a escravização de africanos e descendentes, os fugitivos das áreas mineradoras que se refugiavam nos sertões do Campo Grande deveriam constituir boa parte dos moradores dos povoados quilombolas. É possível que os quilombos contassem também com ameríndios, que ali se misturavam aos africanos. Os quilombos podiam eventualmente abrigar alguns luso-americanos livres fugidos da justiça ou afins, porém, a presença desses indivíduos nos quilombos devia ser restrita. ${ }^{17}$ A associação aos quilombos era arriscada devido à agressividade dos agentes portugueses, que inclusive realizavam punições exemplares, como cortar cabeças dos quilombolas e expô-las em locais públicos. ${ }^{18}$

$\bigcirc$ estabelecimento de povoados luso-americanos e a busca de jazidas minerais estiveram associados nessa região. Os primeiros núcleos coloniais portugueses estabelecidos nas "minas gerais" ficavam na serra do Espinhaço (nome atual), cuja exploração foi iniciada nos últimos anos do século XVII. Mais a oeste, entre as primeiras e mais prósperas jazidas descobertas, estavam as de Pitangui (mais próximas da região estudada, onde foi encontrado ouro em 171 1) e as de Goiás (descobertas por volta de 1725). Algumas minas de ouro prosperavam por anos, provocando o surgimento de aglomerações urbanas em suas imediações; outras não apresentavam minério em volume satisfatório e eram abandonadas rapidamente. ${ }^{19}$
14. Barbosa (1972, p. 8889); Souza, op. cit., p. 115118; Venâncio, op. cit., p. 96-99.

15. Em carta de 1746 , o governador Gomes Freire falava sobre um quilombo no Campo Grande com mais de vinte anos, sobre o qual especulava ter mais de mil habitantes. Ver: Barbosa, op. cit., p. 32.

16. Moura (2004, p. 277 , p. 335-339); Gomes (2018. p. 367-373).

17. Souza (2004, p. 100).

18. Barbosa, op. cit., p. 7273; Guimarães (1999, p. 191-196, 248-253); Souza (1999, p. 98).

19. Barbosa (1971, p. 2730); Russell-Wood (2005, p. 51-81); Fonseca, op. cit., p. 63-77. 
20. Barbosa (1971, p. 27-36); Venâncio, op. cit., p. 99.

21. Barbosa (1971, p. 20).

22. Fonseca, op. cit., p. 118-123; Souza (1999, p. 111-115); Barbosa (1971, p. 13-63).

23. Guimarães (1999, p. 104-171); Moraes (2007, p. 55-85); Resende, op. cit., p. 221-251; Venâncio, op. cit., p. 87-102.
Na zona do Campo Grande e seus arredores, ao menos três povoamentos luso-americanos se originaram em função da descoberta de ouro: Rio das Velhas, Paracatu e Piuhÿ.

As primeiras faisqueiras no Piuhÿ foram encontradas em 1731, mas o volume de ouro estava abaixo do esperado, de forma que sua exploração não prosperou. Em 1736 foi emitida uma ordem régia para abertura de estrada que conectasse as fartas minas auríferas da serra do Espinhaço às de Goiás, passando por Piuhÿ, devendo ser exterminados os povoamentos inimigos que estivessem junto a essa "Picada para Goiás" (nome dado a diferentes estradas que conectavam as minas de Goiás e de Minas Gerais). Como contrapartida pelos serviços prestados ao rei lusitano, os responsáveis por abrir tal picada receberam a concessão de sesmarias na região de Piuhÿ em 1737. Contudo, poucos anos depois, esses sesmeiros abandonaram as terras devido à ação de quilombolas, que rivalizavam com eles pelo povoamento daquela área. Em 1743 foram empreendidos fortes ataques contra os quilombos na região do Piuhÿ, sendo novamente concedidas sesmarias nesse "deserto sertão que até agora servia de couto a negros aquilombados que ali se achavam com grande poder". ${ }^{20}$

As minas de Paracatu foram descobertas em 1744, permanecendo entre as mais prósperas até o início dos anos 1780. A importância de Paracatu estava relacionada à mineração e a sua posição na rota de comunicação entre regiões auríferas de Minas Gerais e Goiás. ${ }^{21}$

Com a decadência das minas auríferas em meados do século XVIII, cresceu o interesse luso-americano por terras cujos relevos e solos fossem apropriados à agricultura e à criação de gado. Razoavelmente próximas das áreas mineradoras densamente povoadas, as terras férteis e abundantemente irrigadas dos sertões do Campo Grande se tornaram visadas pelos súditos portugueses, que procuravam novas minas de ouro, desejavam obter novas terras e pretendiam proteger suas propriedades nos arredores da ameaça de ataques inimigos. ${ }^{22}$

Dessa maneira, entre as décadas de 1740 e 1770, o governo da capitania promoveu diversas campanhas militares cujo propósito era avançar os limites de suas fronteiras de povoamento sobre o sertão do Campo Grande, promovendo uma guerra longeva e de grandes proporções contra "índios bravos" e "negros aquilombados" ali estabelecidos. ${ }^{23}$

Assim, foi somente a partir de meados das décadas de 1740 e 1750 que súditos da coroa de Bragança começaram a estabelecer fazendas para agricultura e pecuária nas bordas do Campo Grande, junto ao Piuhÿ, Tamandoá e à serra da 
Marçella. Continuava ocorrendo, no entanto, a formação de quilombos, concentrados agora na margem ocidental das cabeceiras do rio de São Francisco. ${ }^{24}$

Uma expedição comandada por Bartolomeu Bueno do Prado, em 1756, descobriu faisqueiras de ouro junto ao rio das Velhas (atual rio Araguari), situado para além das serras da Canastra e Marçella. No entanto, a presença de quilombolas e índios Kayapó na região impedia a exploração dessa jazida. Para combater tais "inimigos da colonização lusitana", as câmaras e moradores das imediações prepararam uma expedição, reunindo recursos e tropas por três anos para então adentrar naqueles sertões, saindo de Piuhÿ em agosto de 1759. Nessas batalhas foram destruídos um quilombo nas margens do rio Bamboÿ, o quilombo Grande (também conhecido por Ambrozio) e outros. Em retribuição aos seus serviços de extermínio de quilombolas, Bartolomeu Bueno do Prado recebeu patente militar e sesmaria nos arredores de Piuhÿ. ${ }^{25}$

Orraial de Bambohÿ foi fixado somente depois de conquistadas as imediações de Piuhÿ, tendo seu estabelecimento relacionado à figura de Ignacio Correya Pamplona. Nascido em 1731 na llha Terceira do arquipélago de Açores, no meio do Atlântico, Pamplona era casado com Eugênia Luisa da Silva (filha de pai desconhecido e de mãe africana, trazida da Costa da Mina como escravizada). Ele foi comerciante no Rio de Janeiro, em Vila Rica e em São João del-Rei antes de liderar seis expedições militares para conquista dos sertões do Campo Grande, solicitadas pelo governo da capitania de Minas Gerais. A autopromoção de Pamplona quanto a seus serviços para a coroa the rendeu a patente de chefe civil e militar da vasta região de Piuhÿ, Bambohÿ, Campo Grande e Picadas de Goiás, assim como a concessão de diversas sesmarias nas regiões exploradas para ele e seus familiares, tornando-o um grande potentado local. ${ }^{26}$

A primeira expedição de Pamplona para combater indígenas e quilombolas a oeste do rio de São Francisco foi empreendida em 1765. Os expedicionários dessa campanha requereram concessão de terras para povoarem aquele "sertão inculto" com fazendas de gado, tendo suas petições deferidas em 1767. Por sua vez, a expedição empreendida por Pamplona em 1769, cujos documentos são aqui analisados, fez o reconhecimento da região desde o vale aos pés das serras da Canastra e Piuhÿ, adentrando a cadeia de serras no entorno do rio QuebraAnzol, até as proximidades do ribeirão do Salitre. Em 1769 foi lavrado o auto de posse das paragens de Bambohÿ para o termo da vila de São José, integrante da comarca do Rio das Mortes. No início dos anos 1770, correspondências do governador de Minas Gerais para Pamplona e para o vigário de Pitangui afirmavam a utilidade para o "Real Serviço" da descoberta de faisqueiras e da fixação de povoamentos nos arredores de Bambohÿ (com cultivo das terras, construção de
24. Dados dos documentos do acervo do Arquivo Público Mineiro (APM cód. 129, fl. 99 e 100; cód. 156, fl. 8; cód. 172, fl. 16) apresentados por Barbosa (1971, p. 23-36, 57-58).

25. Barbosa (1972, p. 41-53) 26. Souza (1999, p. 115-118). 
27. Análise de documentos do Arquivo Público Mineiro (APM cód. 103, fl. 23; cód. 145) apresentada por Barbosa (1971, p. 30-39).

28. Souza (1999, p. 116)

29. Barbosa (1971, p. 63 , 1972, p. 72-75).

30. [Mapa da expedição de 1769 de Ignacio Correya Pamplona], [1769?]. Papel. 1 folha, $90 \times 43 \mathrm{~cm}$. Manuscrito. Português. Acervo da Fundação Biblioteca Nacional - Brasil, Coleção Ottoni, Arquivo Conde de Valadares, código: MS-575 (1), folha 245 .

31. [Encontrando Quilombos]. Transcrição e edição por Maria Filgueiras Gonçalves. Anais da Biblioteca Nacional, Rio de Janeiro, v. 108 , p. $47-113,1988$.

32. Araújo (1993). capelas e igrejas para assistência espiritual dos entrantes e estabelecimento de meios de sua permanência). ${ }^{27}$ Em 1782 Pamplona liderou outra expedição ao Campo Grande, nesse caso dedicada a combater indígenas. ${ }^{28}$

Até os anos de 1780, ainda há, na documentação da administração pública luso-americana, testemunhos de confrontos com quilombolas nos arredores de Paracatu e Bambohÿ, registros que vão rareando nos últimos anos do século XVIII. ${ }^{29}$

Com tal panorama em mente, analisemos os documentos sertanistas da expedição de conquista liderada por Pamplona em 1769, que foram destinados ao governo da capitania de Minas Gerais.

\section{OS DOCUMENTOS DA EXPEDIÇÃO DE 1769}

Os relatórios da jornada da conquista dos sertões para além da serra da Marçella, empreendida entre agosto e novembro de 1769, sob comando do mestre de campo, regente e guarda-mor Ignacio Correya Pamplona, são constituídos de duas narrativas textuais "estampadas" com desenhos de implantação do "lugar do Salitre", de seis quilombos (Figuras 1 a 6) e por um mapa com a região desbravada pela expedição (Mapa 1).30 A riqueza de detalhes desses raros registros do interior dos quilombos e de seus locais de implantação fazem com que esses manuscritos sejam extremamente valiosos para os estudos históricos contemporâneos.

Devido à restrição de acesso aos originais e à inexistência de imagens em alta resolução, para analisar os documentos textuais foi utilizada neste artigo sua versão publicada nos Anais da Biblioteca Nacional. ${ }^{31}$ Já para analisar as imagens, foram utilizados os documentos originais, cujas reproduções fotográficas aqui apresentadas foram captadas pessoalmente.

$\mathrm{Na}$ edição paleográfica dos textos integrantes dos documentos iconográficos, procuramos seguir as normas técnicas para transcrição de manuscritos de 1993, conservando a grafia das palavras, pontuação, acentuação e demais elementos de acordo com o original. ${ }^{32}$ Por isso, nas transcrições e na análise foram preservadas as grafias, conforme aparecem no documento, dos nomes próprios de rios, serras, quilombos e demais povoações. Nos desenhos há divergências de grafia em relação aos diários da campanha de Pamplona transcritos nos Anais da Biblioteca Nacional, divergências que se devem às diferenças nos critérios paleográficos adotados. Os desdobramentos das abreviações em desuso, cujas letras ocultas estão sublinhadas na transcrição, foram realizados com o auxílio da 
obra de Maria Helena Flexor. ${ }^{33}$ Os números, letras ou palavras acrescentados pela edição paleográfica estão indicados entre colchetes.

Atualmente sob guarda da Biblioteca Nacional, os documentos analisados estão reunidos em um único códice, cuja encadernação oculta partes dos desenhos e faz com que as dobras nas folhas dentro do pesado volume danifiquem o suporte em papel. Os manuscritos foram feitos sobre folhas importadas de trapo de algodão de alta gramatura, nas quais, contra a luz, vemos a marca d'água da D\&C Blauw. Os textos e desenhos foram feitos com tinta ferrogálica, sem uso de outros pigmentos para coloração das imagens. A ausência de elementos decorativos, cartuchos ornamentados, debruns ou aguadas coloridas mostram que essas peças iconográficas não são edições de luxo. ${ }^{34}$ Todavia, é notório o esforço de fidelidade espacial nas ilustrações, visível nas indicações de escalas em "legoa" ou "passos" 35 incluídas em boa parte dos desenhos ou no detalhamento da rede hidrográfica usada como ponto de referência.

Por falta de estabilização do material lque não recebeu aplicação de reforço para o papel de trapo ou neutralização da tinta ferrogálica), partes significativas das informações dos documentos estão se perdendo em consequência de rasgos, destaques de trechos do papel e migração de tinta para outras páginas. É perceptível a necessidade de cuidados de conservação desses documentos, caso contrário sua deterioração fará com que esses quilombos encontrem em breve uma nova ruína, agora de sua memória.

Adiante, apresentam-se as reproduções dos documentos gráficos, juntamente com a transcrição de seus respectivos textos (replicando a numeração existente nos manuscritos e acrescentando chamadas entre colchetes para os demais textos da imagem). Para facilitar o cruzamento das informações, incluímos chamadas para as transcrições também na análise dos documentos.

Na edição da imagem do Mapa 1 foram reforçados, em vermelho, o trajeto da expedição; em amarelo, as serras da Marçella e da Canastra; em laranja, os quilombos; e, com tracejado em verde, as áreas demarcadas para fundação dos novos povoados luso-brasileiros.

Apresentadas as características e o tratamento das fontes primárias, seguimos agora os rastros deixados pelos expedicionários em seus relatórios para, a partir da análise dos dados neles oferecidos, esboçar algumas características dos quilombos, entender quais eram os interesses e as estratégias de conquista territorial desses agentes da Coroa e quais as relações da nova estrutura colonial lusitana com os quilombos encontrados.
33. Flexor (1990).

34. Santos (2007, p. 51-67).

35. O sistema métrico foi difundido apenas fim do século XIX. Antes disso, eram usadas medidas com referência no corpo humano para realizar as representações gráficas (SANTOS, 2007, p. 68-72). 


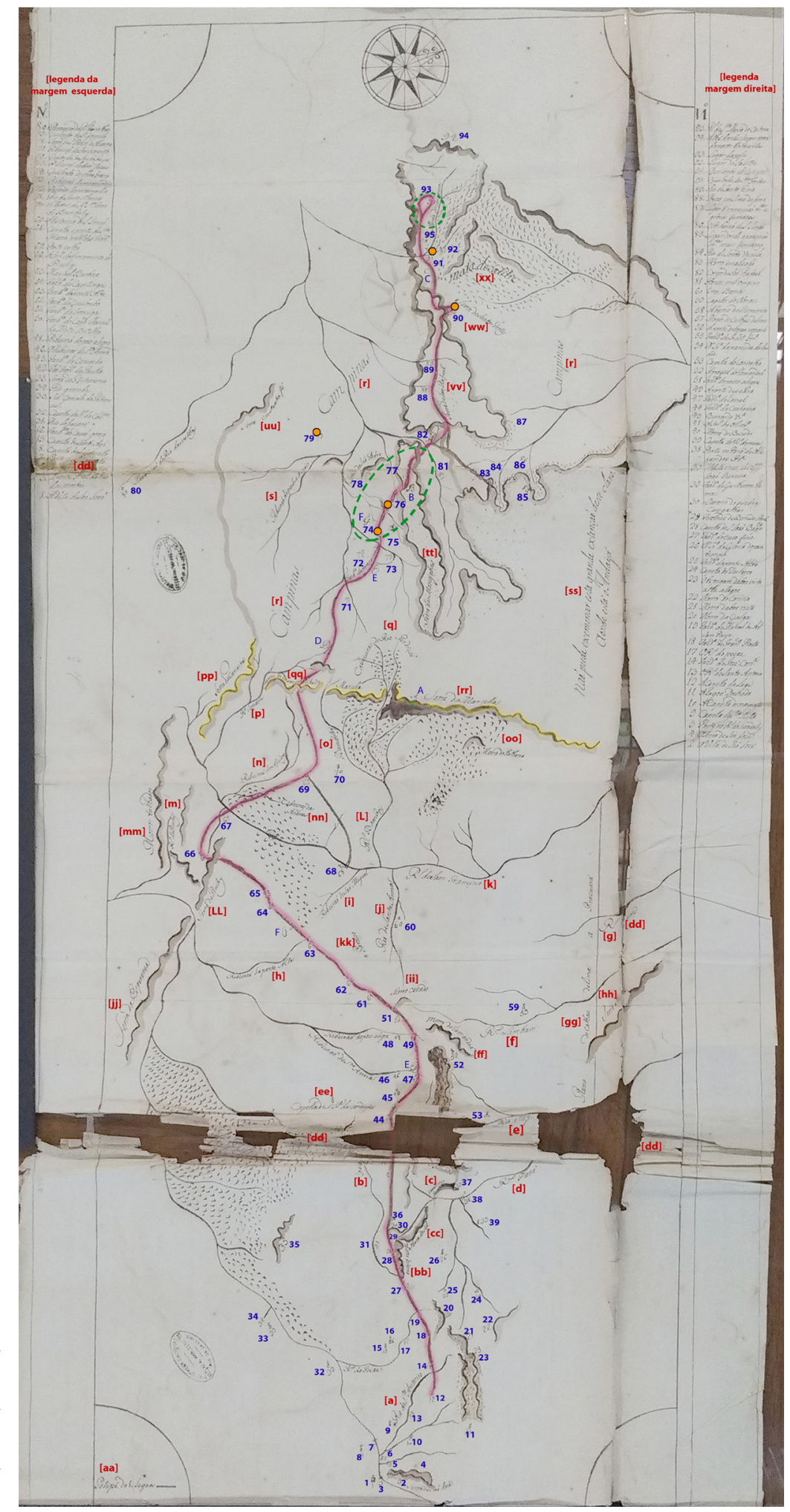

Mapa 1 - [Mapa da expedição de 1769 de lgnacio Correya Pamplona], [1769?]. Papel. 1 folha, $90 \times 43 \mathrm{~cm}$. Manuscrito. Português. Acervo da Fundação Biblioteca Nacional - Brasil, Rio de Janeiro, coleção Ottoni, arquivo conde de Valadares, código: MS-575(1), folha 245. Fotografia da autora. 
Tabela 1 - Edição de textos das legendas das margens laterais do Mapa 1.

\begin{tabular}{|c|c|c|c|}
\hline $\mathrm{N}^{\circ}$ & & $\mathrm{N}^{\circ}$ & \\
\hline $80 / /$ & Pavoação do Rio das velhas & 95 & Rio de Santa Maria Cortona \\
\hline $79 / /$ & Quilonbo de S. Gonçalo. & $94 / /$ & $\begin{array}{l}\text { Athé donde chegou a pose dos novos } \\
\text { Entrantes. }\end{array}$ \\
\hline $78 / 1$ & Serra de S. Pedro de Alcantra & 93,1 & Lugar de poSse \\
\hline 77 & Ribeiraõ do Sacramento. & 92, & Lugar do Salittre \\
\hline $76, / 1$ & Quilonbo da Sanbabaÿa & $91 / 1$ & [Quilonbo do Catigal] \\
\hline $75, /$ & Ribeiraõ do bom Jezus & $90 / 1$ & O Quilonbo dos Santos Fortes \\
\hline $74 / 1$ & Quilonbo do Ambrozio & $89 / 1$ & Rio da Santa Eria. \\
\hline 73,1 & Ribeiraõ da [mizericordia] & $88 / 1$ & Pouzo em Sima da Serra \\
\hline $72, /$ & Fazenda da misericórdia & $87 / /$ & $\begin{array}{l}\text { Lugar que apareceraõ muntas e grosas } \\
\text { fumaças. }\end{array}$ \\
\hline $71 / 1$ & Rio de Santa Thareza & 86,1 & O Ribeirão de S. Simaõ \\
\hline $70, / 1$ & $\begin{array}{l}\text { A Matriz da Sra. Santa Anna de } \\
\text { Bambohÿ }\end{array}$ & $85 / /$ & $\begin{array}{l}\text { Lugar donde apareceraõ muntas mais } \\
\text { fumaças }\end{array}$ \\
\hline 69,11 & A Estançia de S. Simaõ & 84 & Rio de Santa Ursula \\
\hline $68 / 1$ & $\begin{array}{l}\text { Capella, e ponte de Santa Maria, no } \\
\text { Rio de S. Francisco }\end{array}$ & 83 & Morro escalvado \\
\hline 67 & Porto velho. & 82 & Corgo de Saõ. Rafael \\
\hline 66 & A Snr ${ }^{a}$. do livramento do Piuhÿ & 81 & Honze mil virgens \\
\hline 65,1 & Manoel Barboza & 60 & Tres Barras \\
\hline $64 / 1$ & Fazenda da Capitinga. & 59 & Capella do Moraes \\
\hline $63 / 1$ & Fazenda da ponte Alta & 58 & A barra da ltapeserica \\
\hline $62 / 1$ & Fazenda do Quilonbo & 57 & Morro de Calhau de lima \\
\hline $61 / 1$ & Fazenda da Fromiga & 56 & A ponte do Lopes no pará \\
\hline 50 & $\begin{array}{l}\text { Fazenda do Cappitão Manoel da Mota } \\
\text { Botelho. }\end{array}$ & 55 & Fazenda de Francisco Ferreira \\
\hline $48 / /$ & Ribeiraõ do pozo alegre & 54 & N. Sra . da pareçida do Claudio. \\
\hline $46 / 1$ & Ribeiraõ de Santa Anna & 53 & Capella do Carvalho \\
\hline $45 / 1$ & Fazenda do Camacho. & 52 & Arraÿal do Tamandoá. \\
\hline $42 / /$ & Saõ Francisco de Paulla. & 51 & Fazenda do pouzo alegre \\
\hline $35 / 1$ & Serra da lbituruna & 49 & A ponte de pedra \\
\hline $34 / /$ & Rio grande & 47 & Fazenda do Corral \\
\hline $33 / /$ & Saõ Goncalo da Ibituruna. & 44 & Fazenda da Cachoeira \\
\hline $32, /$ & Capella da Sra. da Conceição & 43 & Bernardo Vieira \\
\hline
\end{tabular}




\begin{tabular}{|c|c|c|c|}
\hline $\mathrm{N}^{\circ}$ & & $\mathrm{N}^{\circ}$ & \\
\hline $31 / 1$ & Rio do Jacarê. & 41 & A Sra da Oliveira \\
\hline 16,1 & Fazenda do Capaõ groço. & 40 & Morro do Bicudo \\
\hline $15 / 1$ & Capella de SantiAgó & 39 & Capella do Rio do peixe \\
\hline $8 / 1$ & Capella de S. Gonçallo & 38 & Ponte no Pará de Alexandre Pereira \\
\hline $7 / 1$ & Ponte de S. Gonçallo & 37 & A bella Cruz, do Cappitão João Teixeira \\
\hline 6,1 & Capella de S. [Sebastião.] & 36 & Fazenda de Guilherme Ferras \\
\hline $3 / /$ & A ponte Rial do Rio das mortes. & $30, /$ & O morro do quebra Cangalhas. \\
\hline \multirow[t]{22}{*}{$1 / /$} & A Villa de Saõ Joaõ. & 29 & Fazenda de Bernado Homé \\
\hline & & 28 & Capella de S. Joaõ Bapptista \\
\hline & & 27 & Fazenda do Ouro fino. \\
\hline & & 26 & N. Sra. da Gloria do pasa tempo. \\
\hline & & 25 & Fazenda da ponte Alta \\
\hline & & 24 & Capella do Desterro \\
\hline & & 23 & Espigam da boa vista athe a lagoa \\
\hline & & 22 & Morro do Corisco \\
\hline & & 21 & Morro da boa vista \\
\hline & & 20 & Morro da Galga \\
\hline & & 19 & $\begin{array}{l}\text { Fazenda de Manoel de Araúio Sam } \\
\text { Paÿo. }\end{array}$ \\
\hline & & 18 & Fazenda de Francisco Pinto. \\
\hline & & 17 & $\bigcirc$ Rio do peixe \\
\hline & & 14 & Fazenda de Josê Correa \\
\hline & & 13 & O Rio de Santo Antonio \\
\hline & & 12 & A Capella da Laje \\
\hline & & 11 & A Lagoa Dourada \\
\hline & & 10 & A Capella do mosquito \\
\hline & & 9 & Capella de S'a. Ritta \\
\hline & & 5 & Ponte no Rio do Crandahÿ \\
\hline & & 4 & A Serra de Saõ Jozê \\
\hline & & 2 & A Villa de Saõ Jozê \\
\hline
\end{tabular}


Tabela 2 - Legendas acrescentadas pela edição paleográfica ao corpo do Mapa 1.

\begin{tabular}{|c|c|c|c|}
\hline [a] & Rio de Santo Antonio & [aa] & Petipê de 1// Legoa \\
\hline [b] & Rio Jacarê & [bb] & Morro do ferro \\
\hline$[c]$ & vera cruz & {$[\mathrm{cc}]$} & Serra do Sal \\
\hline [d] & Rio Parâ & [dd] & $\begin{array}{l}\text { [perdas de materialidade e informações } \\
\text { do documento] }\end{array}$ \\
\hline$[e]$ & Rio [ilegível] & [ee] & Capella de N. Sra. das candeias [?] \\
\hline$[f]$ & Rio Lambari & {$[\mathrm{ff}]$} & Morro do Tamandoá \\
\hline [g] & Rio [ilegível] & [gg] & Rumo de calhau de lima a Piracuará \\
\hline$[h]$ & Ribeiraõ da ponte Alta & {$[\mathrm{hh}]$} & Serra [ilegível] \\
\hline [i] & Ribeiraõ de São Miguel & [ii] & Morro cavado \\
\hline [i] & Rio de Santa Anna & [ii] & Serra da Esperança \\
\hline$[k]$ & Rio de Saõ Francisco & {$[\mathrm{kk}]$} & Paraizo \\
\hline$[\mathrm{L}]$ & Rio Bamboÿ & {$[L L]$} & Serra de Piuhÿ \\
\hline [m] & Rio de Piuhy & {$[\mathrm{mm}]$} & Morros talhador \\
\hline$[n]$ & Ribeirão das Ajudas & {$[\mathrm{nn}]$} & Cabeceras das Araras \\
\hline [0] & Bambohÿ & [oo] & Morro do Palhano [?] \\
\hline [p] & Rio Sambora [?] & [pp] & Serra da Canastra \\
\hline [q] & Cabeceiras do Rio Perdiçaõ & [qq] & Morro do desempinhado \\
\hline$[r]$ & Campinas & {$[\mathrm{rr}]$} & A Serra da Marçella \\
\hline \multirow[t]{6}{*}[s]{} & Ribeirão do quebra [Anzois] & {$[s s]$} & $\begin{array}{l}\text { Naõ pude exeminar esta grande exten- } \\
\text { çaõ deste claro. Aonde está o Andayá }\end{array}$ \\
\hline & & {$[\mathrm{H}]$} & Serra das Mangabas \\
\hline & & [uv] & Serra em Santa Fê \\
\hline & & {$[\mathrm{vv}]$} & Serra de São Rafael \\
\hline & & {$[w w]$} & Serra de Santos Fortes \\
\hline & & {$[x x]$} & Mata do Salitre \\
\hline
\end{tabular}




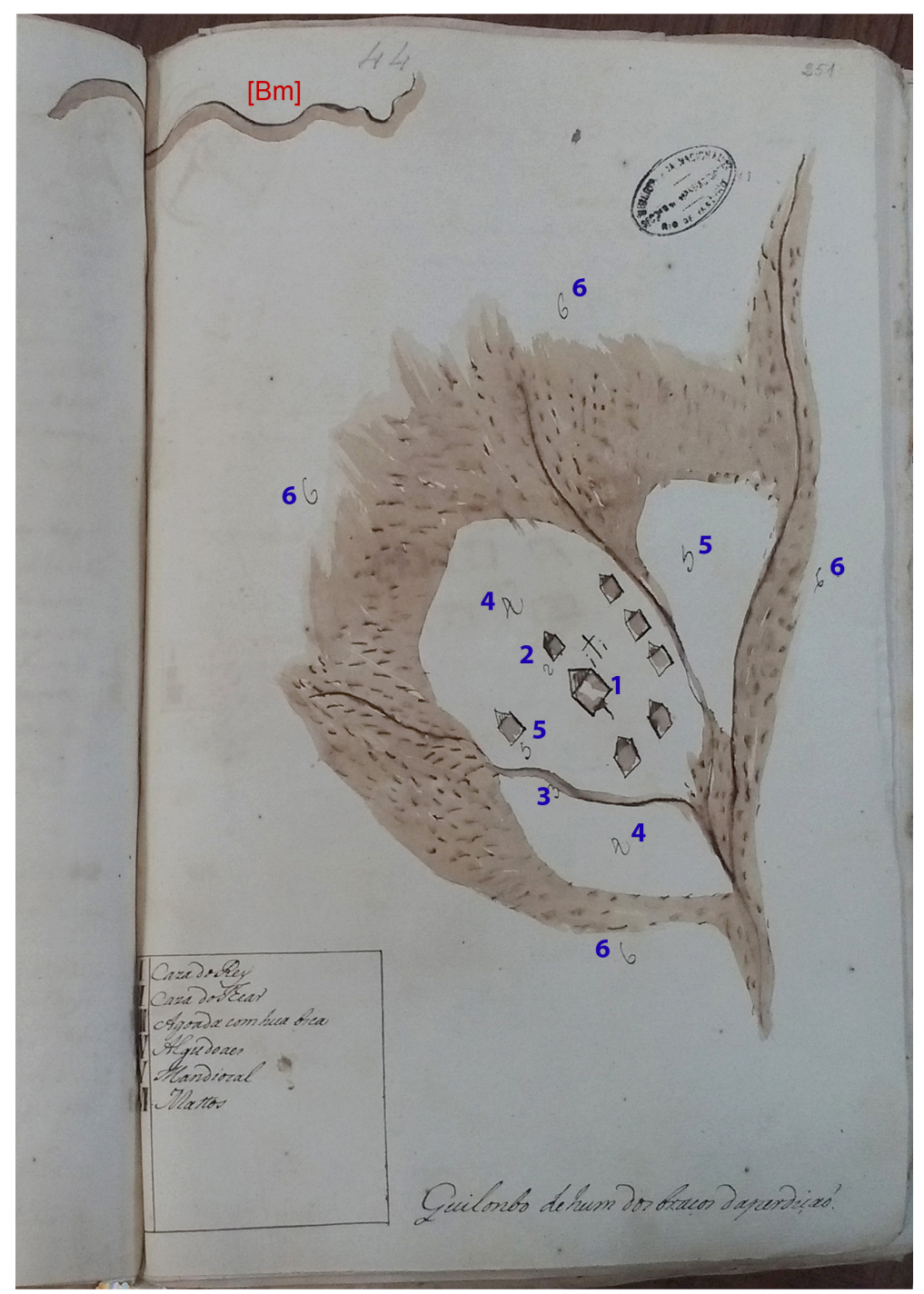

Figura 1 - Quilonbo de hum dos braços da perdiçaõ, [1769?], Papel. 2 folhas. Manuscrito. Português. Acervo da Fundação Biblioteca Nacional - Brasil, Rio de Janeiro, coleção Ottoni, Arquivo Conde de Valadares, código: MS-575(1), folhas 250-251. Fotografia da autora.

I Caza do Rey

I $\quad$ Caza do Thear

III $\quad$ Agoada com hua bica

IV Algudoaes

$\checkmark \quad$ Mandiocal

VI Mattos

[Bm] Morro 


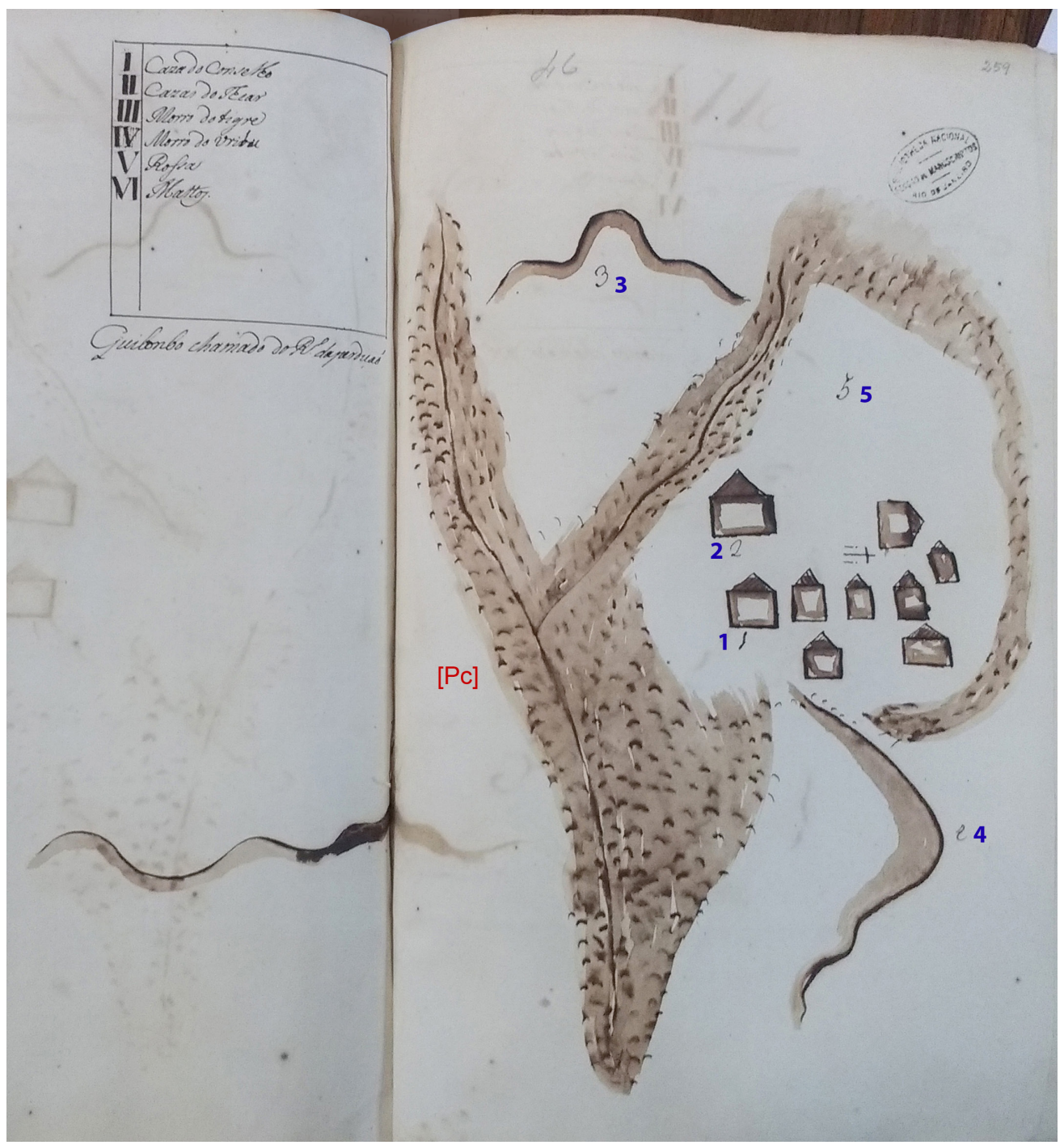

Figura 2 - Quilonbo chamado do Rio da perdiçaõ, [1769?], Papel. 2 folhas. Manuscrito. Português. Acervo da Fundação Biblioteca Nacional - Brasil, Rio de Janeiro, coleção Ottoni, Arquivo Conde de Valadares, código: MS-575(1), folhas 258-259. Fotografia da autora.

$\begin{array}{ll}\text { I } & \text { Caza do Conselho } \\ \text { II } & \text { Cazas do Thear } \\ \text { III } & \text { Morro do tigre } \\ \text { IV } & \text { Morro do Uribu } \\ \text { V } & \text { RoSsa } \\ \text { VI } & \text { Mattos. } \\ \text { [Pc] Veios d'água }\end{array}$




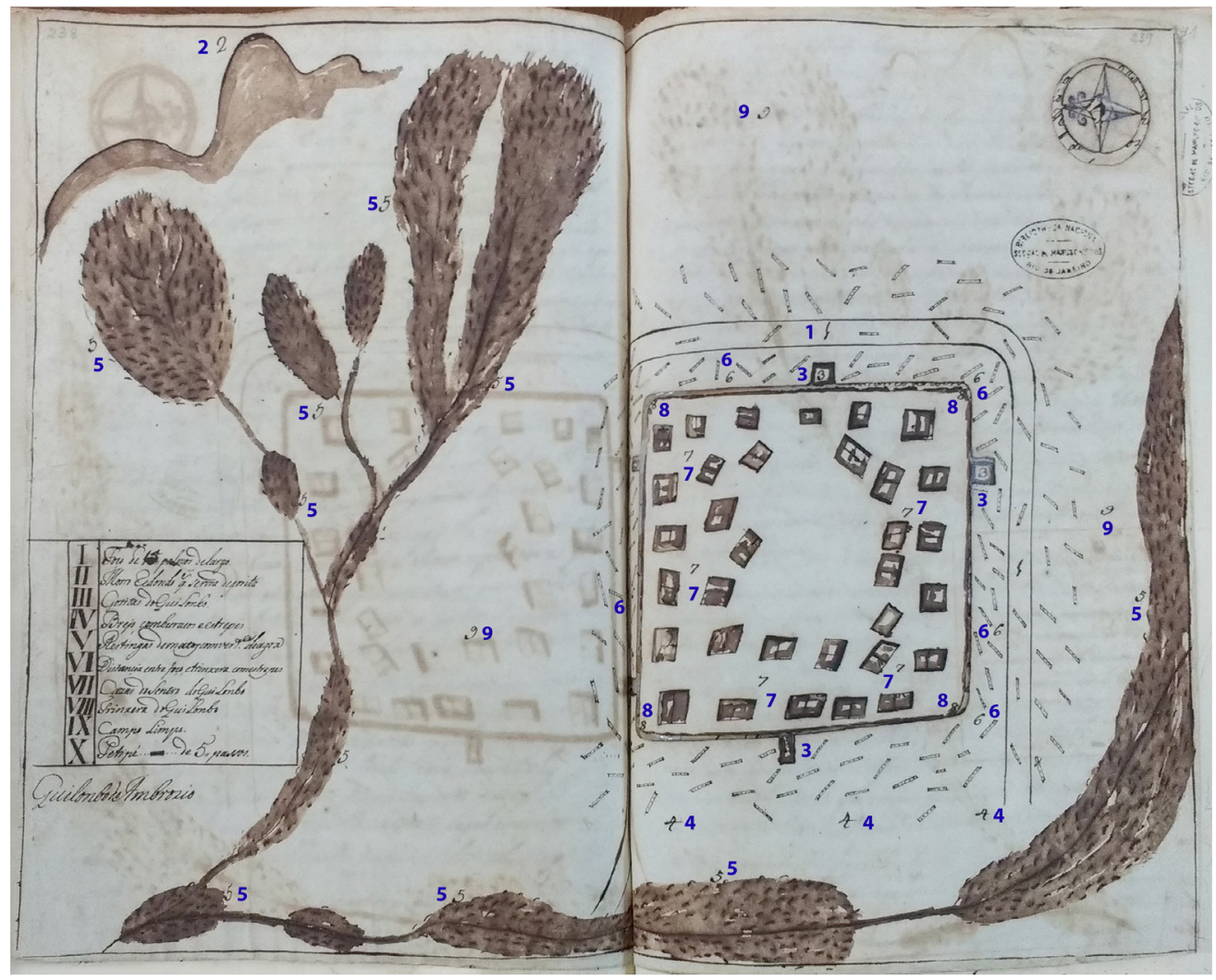

Figura 3 - Quilonbo do Ambrozio, [1769?], Papel. 2 folhas. Manuscrito. Português. Acervo da Fundação Biblioteca Nacional - Brasil, Rio de Janeiro, coleção Ottoni, Arquivo Conde de Valadares, código: MS-575(1), folhas 238-239. Fotografia da autora.

I Foço de 15// palmos de largo.

I $\quad$ Morro Redondo que servia de gorita

II Goritas do Quilonbo.

IV Brejo, com buracos e estrepes

$\checkmark \quad$ Restingas de matos com vertentes de agoa

VI Distançia entre foço, e trinxera com estrepes.

VII Cazas do Sentro do Quilonbo

VIII Trinxera do Quilonbo

IX Campo Limpo.

X Petipé...[traço para medida de escala gráfica] de 5// passos. 


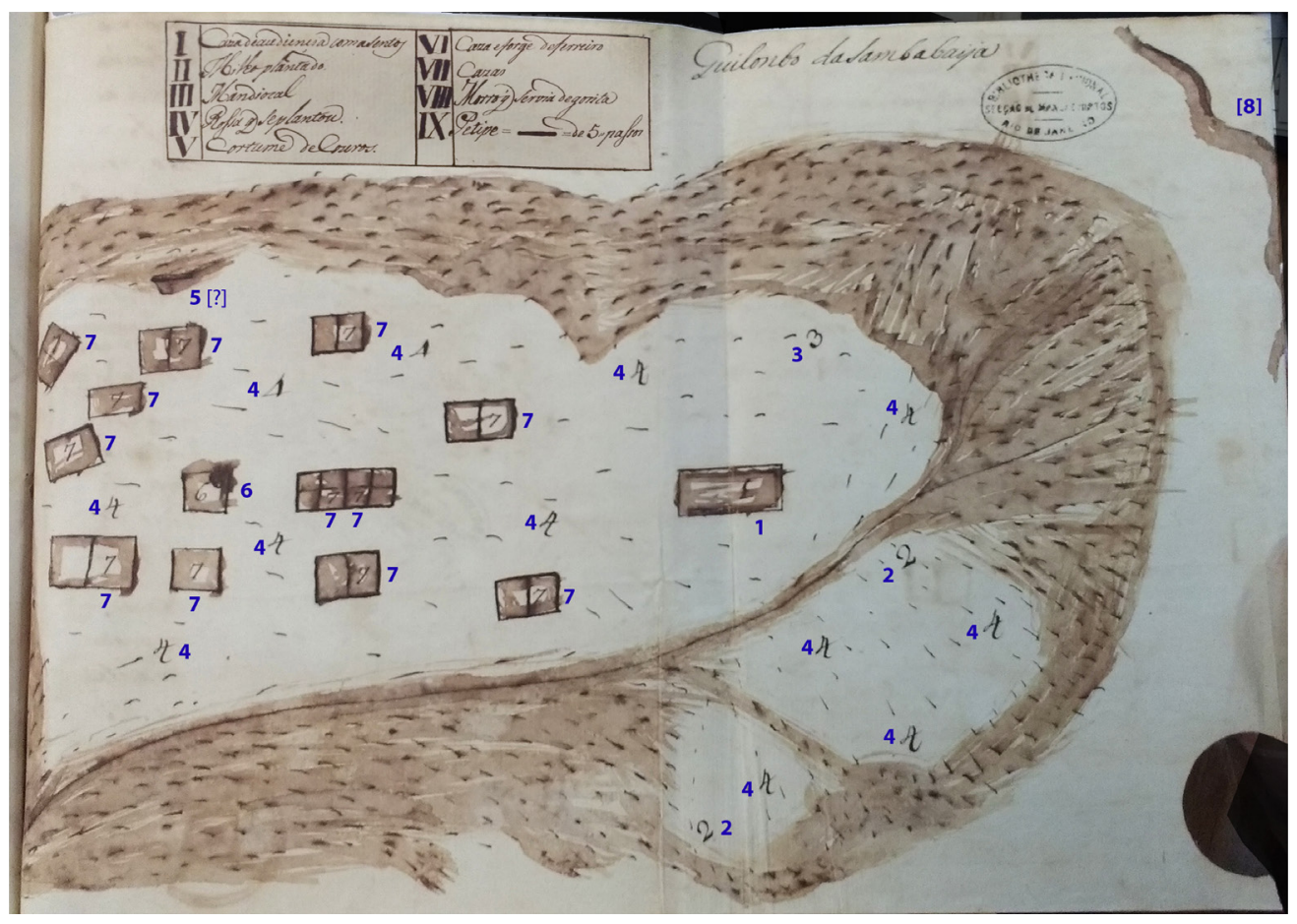

Figura 4 - Quilonbo da Sambabaÿa, [1769? ], Papel. 1 folha. Manuscrito. Português. Acervo da Fundação Biblioteca Nacional - Brasil, Rio de Janeiro, coleção Ottoni, Arquivo Conde de Valadares, código: MS-575(1), folha 243. Fotografia da autora.

I Caza de audiençia com aSentos.

॥ Milho plantado.

III Mandiocal.

IV RoSia que se plantou.

V Cortume de Couros.

VI Caza e forge de ferreiro

VII Cazas

VIII Morro que servia de gorita

IX Petipe $=[$ traço para escala $]=5 / /$ paSsos 


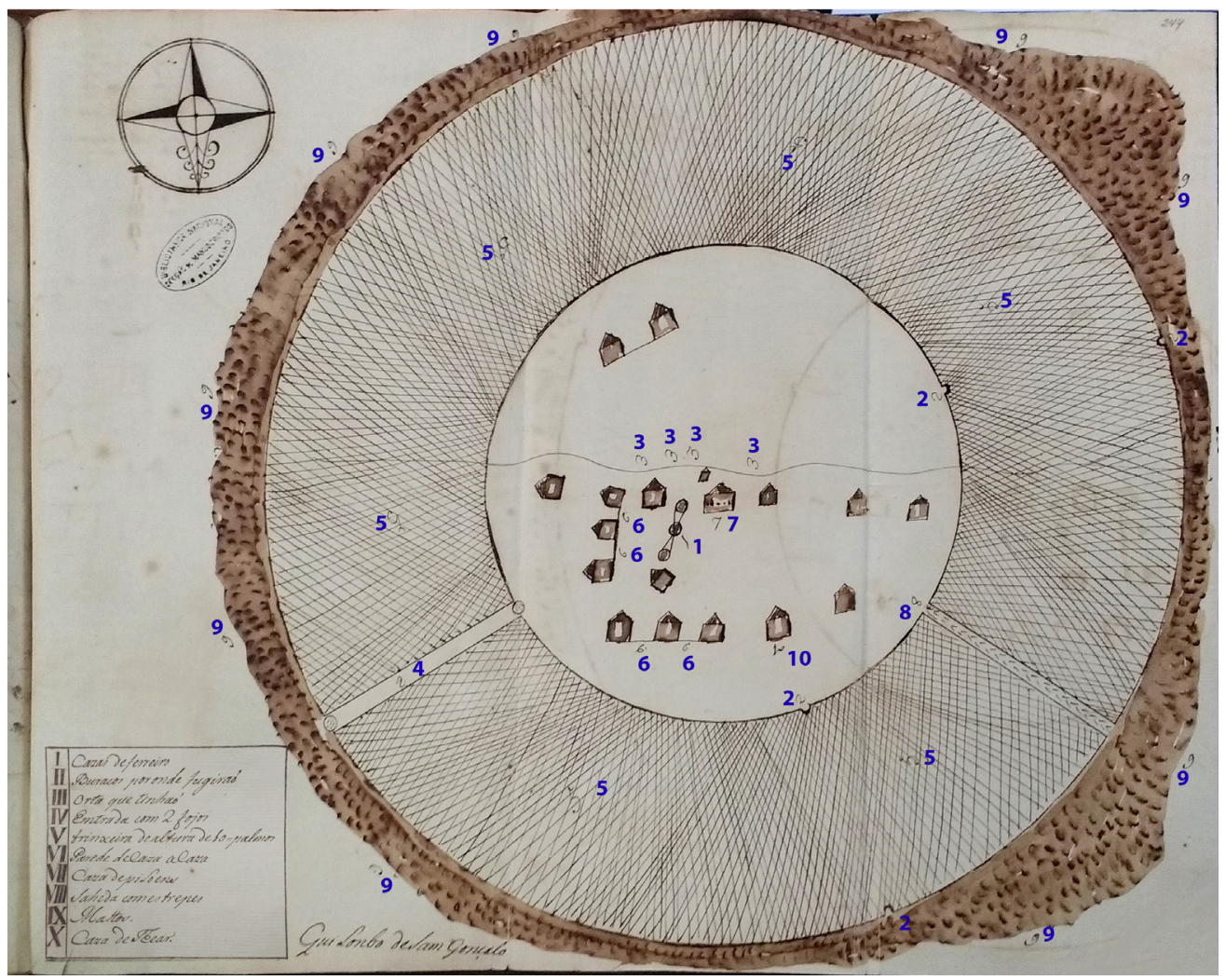

Figura 5 - Quilonbo de Sam Gonçalo, [1769?], Papel. 1 folha. Manuscrito. Português. Acervo da Fundação Biblioteca Nacional - Brasil, Rio de Janeiro, coleção Ottoni, Arquivo Conde de Valadares, código: MS-575(1), folha 244. Fotografia da autora.

I Cazas de ferreiro

\| Buracos por onde fugiraõ

III Orta que tinhaõ

IV Entrada com 2 fojos

$\checkmark \quad$ trinxeira de altura de 10// palmos

VI Parede de Caza a Caza

VII Caza de piloens

VIII Sahida com estrepes

IX Mattos.

X Caza de Thear. 


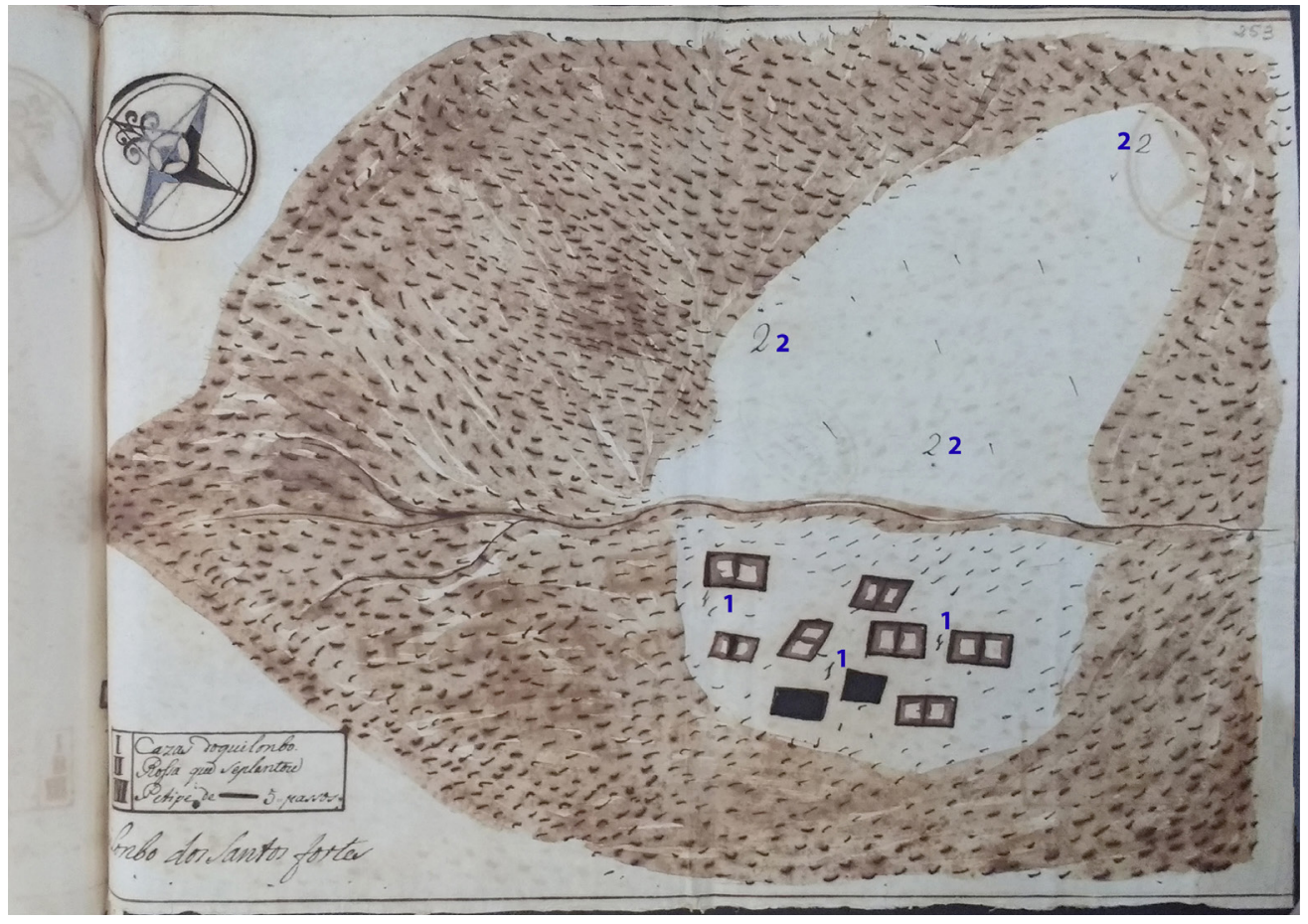

Figura 6 - [Quilonbo] dos Santos fortes, [1769?], Papel. 1 folha. Manuscrito. Português. Acervo da Fundação Biblioteca Nacional - Brasil, Rio de Janeiro, coleção Ottoni, arquivo conde de Valadares, código: MS-575(1), folha 253. Fotografia da autora.

I Cazas do quilonbo.

I $\quad$ RoSsa que se plantou

III Petipé de [traço para medida de escala gráfica] 5// passos.
36. Légua é uma medida de comprimento empregada na cartografia que se refere ao corpo humano e tem como referência astronômica uma fração do arco de meridiano terrestre de um grau. Na cartografia da América portuguesa a légua corresponde a 3 mil braças, que equivalem a cerca de $6.522 \mathrm{~m}$, dimensões que eram representadas com exatidão dependendo dos instrumentos e técnicas de medição disponíveis. Tomada por aproximação, uma légua corresponde a uma hora de caminhada a passo cheio (BUENO, 2007, p. 29-49; SANTOS, 2007, p. 51-81).

\section{A JORNADA DE CONQUISTA DO SERTÃO DO CAMPO GRANDE DE 1769}

No inverno de 1769 partiu dos arredores da vila de São João(1) uma expedição bélica cujo propósito era conquistar parte do sertão do Campo Grande, na margem oeste das cabeceiras do rio de São Francisco, tomando posse da região em nome do governador da capitania de Minas Gerais. Os objetivos expressos da campanha eram identificar novas jazidas de ouro, destruir quilombos e facilitar o povoamento daquela região.

Avançando entre 2,5 e 8 léguas ${ }^{36}$ por dia de marcha, a tropa saiu em meados de agosto das proximidades do rio de Santo Antônio[a], afluente do rio 
37. [Encontrando Quilombos]. Transcrição e edição por Maria Filgueiras Gonçalves. Anais da Biblioteca Nacional, Rio de Janeiro, v. 108,1988 , p. $53-56$ )

38. Ibid., p. 53-96.

39. Ibid., p. 96-113.

40. Ibid., p. 57-60, 67.
Grande ${ }^{(34)}$, atravessou o rio de São Francisco[k] e a serra da Marçella $a^{[r]}$, seguindo sertão adentro até pouco além da paragem do Salitre ${ }^{[x]}$ (Mapa 1), dali retornando para o ponto de partida, encerrando a jornada no fim de novembro de 1769.

Saíram inicialmente com 52 bestas de carga com comestíveis, bebidas e boticas, alguns cavaleiros, 58 escravizados "com armas de espingarda, clavinas, facões, patrona, pólvora, chumbo, e bala", dois "pretos tambores, com suas caixas cobertas de encerado", oito músicos (dentre os quais sete também eram escravizados) com "violas, rebecas, trompas e flautas travessas", juntamente com seu proprietário e líder da expedição, Ignacio Correya Pamplona, que acumulava os tífulos de mestre de campo, regente e guarda-mor "de todas as picadas de Goiases, Bamboí e Piuí". Durante o percurso, juntaram-se às tropas um reverendo capelão, um "surigião", soldados pagos, homens recrutados e outros. ${ }^{37}$

Acompanharam a jornada ao menos dois diferentes memorialistas anônimos: um autor da "Notícia diária e individual das marchas [...]", que apresentou os "sucessos de cada dia" da campanha de conquista do sertão; ${ }^{38}$ e outro responsável pelos desenhos do mapa do trajeto percorrido pela expedição e de seus arredores (Mapa 1), pelos desenhos de implantação dos quilombos (Figuras 1 a 6) por onde passaram e pelo desenho do lugar do Salitre, assim como pelos textos associados às ilustrações, ${ }^{39}$ que nesta análise foram batizados de "Memorial dos Mapas".

A rotina da comitiva foi destacada em seu diário: ao romper da aurora eram tocadas as caixas da alvorada, os músicos executavam seus minuetos, era celebrada a missa, servido o almoço e então as tropas se dedicavam aos serviços do dia. Para abrir caminho para a expedição, escravizados com foices, machados e enxadas rompiam os matos, faziam pontes sobre os córregos e ribeirões, construíam ranchos para o descanso das tropas. ${ }^{40}$ Durante 0 trajeto, o mestre de campo nomeou diversos capões do mato, cursos d'água e serras ainda não batizados por representantes da coroa portuguesa. Ao longo do percurso, alguns "magnatas do País" vieram ao encontro do regente, ofertando poemas, solicitando terras e o apaziguamento de contendas. Nos povoados por onde passou, Pamplona prendeu e emitiu ordens de prisão para algumas pessoas, enquanto o reverendo capelão batizava crianças e tomava confissões.

Transcorridas apenas cinco léguas para além da capela de Nossa Senhora da Oliveira, os expedicionários relataram não terem achado mais "gente de qualidade algũa, mais que um pobre velho" em um sítio composto de duas casas velhas de capim, ameaçadas de ruína. Chegando ao povoado de Piuhÿ|(6)|, o mestre se "enfadou contra a gente tão bárbara e endômita, que 
abusavam de Deus, e de seus santos, por não conservarem um templo", ordenando a construção de uma igreja. ${ }^{41}$

Seguindo em direção ao rio de São Francisco[k], chegaram às suas margens no Porto velho|b7|, cuja travessia das pessoas foi feita por meio de canoas, enquanto os animais atravessaram a nado, levando seis dias para passar todo o "trem". A expedição dedicou aproximadamente um mês de trabalho para construir uma ponte em madeira sobre o rio(68). Para a inauguração foi feita uma procissão solene, com marcha sobre a ponte, celebração de missa na capela de São Francisco de Sales e Santa Maria (que também construíram), seguida de um "banquete onde se contavam 65 homens brancos", que declamaram poemas e fizeram requerimentos de sesmarias. Pamplona questionou-thes se tinham condições de "fabricarem as ditas 3 léguas de terras". Em resposta, tais requerentes "Ihe deziam um tinha oito Negros, outro dez, e outro doze". A construção da ponte foi destacada por um dos memorialistas como um

serviço tão útil à real Coroa como necessário ao bem comum e aos novos entrantes, cujos já passaram de duzentos, a qual entrada the facilitou a dita ponte de tal sorte que em breves tempos, se verá aquele País coltivado de Abondantes povos de que o Irário Real receberá grande otilidade. ${ }^{42}$

Os expedicionários seguiram então para o arraial de Nossa Senhora Santa Anna de Bambohÿ(70), na margem oeste do rio de São Francisco, onde Pamplona mandou erguer a nova capela-mor da freguesia. Dali, o Mestre de Campo despachou duas bandeiras para a outra parte da serra da Marçella, uma comandada por José Serra e outra por José Cardoso, que partiram no início de setembro. Esses destacamentos retornaram cerca de um mês depois: um deles não achou o ouro procurado, enquanto o outro encontrou dois quilombos próximos ao rio da Perdição[a], apresentando "notícia dos Negros, que tinham morto, dos que tinham fugido e de um que trouxeram amarrado". ${ }^{43}$

Para a travessia da serra da Marçella[rr], todas as tropas foram reunidas na fazenda de Pamplona ${ }^{(69)}$, nos arrabaldes de Bambohÿ ${ }^{(70)}$, onde prepararam as armas, distribuíram pólvora, chumbo e bala para prevenção dos viajantes. A campanha partiu dali em meados de outubro com 96 pessoas (42 cavaleiros e 54 pedestres), 42 bestas de carga e dois cavalos "adestra". ${ }^{44}$

No segundo dia de jornada para além da serra da Marçella[r] a expedição chegou às ruínas do Ambrozio(74), "quilombo não afamado nestas minas como prejudicial aos moradores delas", onde admiraram "os arruinados idifícios e 
45. Ibid., p. 67-70, 101.

46. Ibid., p. 70-71, 101.

47. Tapijara é termo derivado do tupi que designa o prático, aquele que conhece os caminhos ou uma região.

48. [Encontrando Quilombos]. Transcrição e edição por Maria Filgueiras Gonçalves. Anais da Biblioteca Nacional, Rio de Janeiro, v. 108,1988 , p. $68,71$.

49. Ibid., p. 71-72. multiplicados fojos, todos crivados de estrepes". Implantado em área de restinga de capoeira, o extinto povoado ficava junto a um córrego, onde as tropas aquartelaram por sete dias, quando metade das gentes foi examinar os córregos e ribeirões vizinhos à procura de mostras de ouro, enquanto a outra parte se dedicou ao cultivo, passando fogo na terra para plantar feijão, algodão e seis alqueires de milho. ${ }^{45}$

Finalizados os trabalhos no Ambrozio, foram a cavalo até a paragem do Sambabaÿa(76), "onde tinha um quilombo de Negros", por sobre o qual as tropas plantaram uma roça de milho, feijão e algodão. Ainda no mesmo dia seguiram para o rio das Honze mil virgens ${ }^{[811}$. Novamente buscaram ouro nos veios d'água das imediações, mas sem resultados. Ali, Pamplona destinou a área entre o córrego do Sacramento(77), córrego do Bom Jesus ${ }^{(75)}$ e a serra de São Pedro de Alcantra ${ }^{(78)}$ até 0 quilombo do Ambrozio(74) (polígono que abrange $\circ$ quilombo da Sambabaÿa(7b)| para a constituição de sua própria fazenda e patrimônio de Nossa Senhora da Conceição, determinando o sítio para fundação do novo arraial. ${ }^{46}$

O temor de integrantes das tropas acerca dos quilombolas se destacou na narrativa desde a marcha para a serra da Marçella, engrossando os murmúrios e "receio dos negros" à medida que adentravam naquela região. Seguindo viagem pela serra das Mangabas ${ }^{[[]]}$e de São Rafael[w] avistaram "grandes fomaças" ${ }^{\text {(85/87], }}$ "julgando os mais Tapijaras" do Sertão, que eram muntos negros que se avezinhava" à comitiva, que receava ir explorá-los por constituírem "um grande perigo e que os quilombos eram muntos para aquela parte segundo os sinais dos mesmos fogos e que era pública mente notório que havia para ali quilombo que se compunha de mais de duzentos negros". ${ }^{48}$

Para reconhecer as áreas que estariam "infestadas de Negros", Pamplona mandou buscar toda bagagem e tropas para engrossarem "o número da gente e das armas". Sob comando de José Cardoso, foram enviadas 42 pessoas, com pólvora, chumbo e balas e mais armas curtas para examinarem os locais onde os quilombolas poderiam estar refugiados e, caso encontrassem vestígios, deveriam mandar avisar para socorrê-los. Tal bandeira marchou dois dias inteiros, "rompendo matos e Serras fragosas", sem achar os quilombos. Os fogos indicavam estarem por perto, porém deveriam estar "mais amarados ao Sertão". No entanto, como não tinham quem os guiasse "à paragem e habitação dos mesmos Negros", toda a diligência era frustrada e perigosa. ${ }^{49}$

Continuando com a marcha pelo alto do chapadão da serra de São Rafae [ww], avistaram o lugar do quilombo de Sam Gonçalo|(79), em meio a uma área de campina[r]. Uma das bandeiras, comandada pelo tenente José da Serra Caldeira, foi até o local, onde prendeu um quilombola que estava fazendo farinha, 
enquanto os demais fugiram. A tropa confiscou a farinha e "vários trastes e panos de Algudões feitos ricamente pelos mesmos Negros". 50

restante das tropas seguiu caminho até o pé da serra e, afastando-se cerca de uma légua e meia da picada velha de Goiás, o mestre de campo e mais quarenta pessoas, "todos a pé mas bem armados, foram penetrando uns Capões de Matos por serras altivas, ásperas e fragosas, encaminhando-se ao lugar de um quilombo, chamado Corisco". Chegaram a "a ele prevenidos de toda a precisa cautela, porém foi baldada esta deligência, porque os Negros talvez tendo nos avistado por meio de Suas espias, desertaram". Próximo a um córrego de águas abundantes, o local foi intitulado "Santos fortes". Ali, uma parte dos homens foi procurar metais preciosos nos córregos, achando apenas algum esmeril, enquanto outra parte plantou milho, feijão, abóboras, mamona, mandioca e favas. ${ }^{51}$

A campanha continuou a viagem margeando a serra de São Rafael[ww], chegando, no dia $1^{\circ}$ de novembro, ao ribeirão do Salitre, "aonde esteve já muntos anos e há poucos se tornou a retificar um quilombo chamado o Catiguá(191), de mais de cento e cinquenta jiraus, [... ] e agora de próximo se retiraram temoratos das nossas Bandeiras". Os invasores colheram os restos de milho deixados pelos quilombolas para "dar a algum cavalo mais frouxo". Sobre as terras desse quilombo as tropas armaram "um Arraial de casas de capim mui bem airoso, porque a paragem é de Si mesmo mui vistosa e agradável." Ali "apanharam bastantes caças de viados, perdizes, e Jacuses" e no rio pescaram "treze peixes, com o nome de Tobaranas de munto boa grandeza". Nessa região perceberam algum sinal de ouro, porém em quantidade insatisfatória: "em cada bateada eram ũa faisquinha, duas até três, mas mui finas". 52

A comitiva partiu a cavalo examinando os arredores para estabelecer o novo

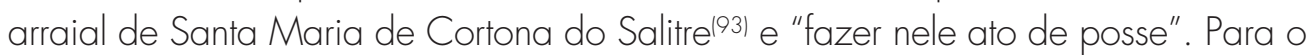
rito de fundação foram ao alto da serra, tocaram as caixas para juntar a gente toda, fizeram cruzes com pau de sucupira do campo, onde colocaram imagens religiosas, rezaram, tocaram trompas, flautas, violas, rebecas e cantaram. $\bigcirc$ mestre de campo então pronunciou que "tinha vindo por mandado do [...] Conde Valadares, Governador e Capitão General desta Capitania de minas gerais, para repartir aquelas terras a quem Ihas pedir" e, uma vez deferidos os requerimentos por sesmarias, deviam cuidar "em povoar o que tinham pedido", visto que o General não queria as terras devolutas. Pamplona encerrou ali a exploração, pois "não podia avançar mais Sertão, sem que primeiro se pavoasse aquele para que os que fossem ficando mais distantes tivessem nos daquele lugar sacorro de mantimentos" ${ }^{53}$

Os expedicionários voltaram para o quilombo do Catiga||(1) para irem até uma paragem "misteriosa", distante dele pouco mais de uma légua, abrindo 
54. Ibid., p. 75, 78-79.

55. O termo "calhambola" (usado nos documentos oficiais da época da escravidão para identificar o negro fugido, fosse ameríndio ou afrodescendente) pode ser usado como sinônimo de quilombola (MOURA, 2004, p. 79).

56. [Encontrando Quilombos]. Transcrição e edição por Maria Filgueiras Gonçalves. Anais da Biblioteca Nacional, Rio de Janeiro, v. 108,1988 , p. $79-81$.

57. Ibid., p. 90-96. caminho por entre os matos "ásporo e terrível" com foices, machados e enxadas, a fim de entrarem os cavaleiros junto com o mestre ao Salitre|${ }^{|92|}$. $O$ local era cercado por árvores frondosas, com muitos pássaros e animais. Corriam ali duas fontes de águas claras, escorregadias como sabão, cuja água tinha cheiro de pólvora e travava na língua. Os cavalos beberam, ficando "bem purgados", e dois escravizados pelo mestre curaram suas feridas com essas águas. Novas experiências de busca de ouro foram feitas, mas sem resultados. ${ }^{54}$

O regresso da expedição para os arredores de São João(1), de onde tinham saído havia meses, foi marcado pelo retorno aos quilombos por onde passaram na ida, agora transmutados em pousos para as tropas. Saindo no início de novembro do Catiga| ${ }^{|91|}$, onde armaram rancho, passaram pelo quilombo dos Santos Fortes ${ }^{(90)}$, onde tinham ficado "um pardo e dous pretos" cuidando de um animal doente, que disseram que "os Negros calhambolas ${ }^{55}$ os tinham andado espiando de noute". Ali avistaram fumaças no interior, que julgaram ser quilombolas, "pois como no Sertão não mora mais ninguém, é infalível consequência que os fogos haviam ser dos mesmos Negros". Dois dias depois chegaram novamente ao quilombo do Ambrozio(74), onde viram nascido e bonito o milho que as tropas plantaram anteriormente. Mais dois dias de marcha e chegaram ao pé da serra da Marçella $a^{[r]}$, onde tocaram as caixas para reunir a gente. Pamplona então se despediu do lugar, lembrando que deviam ir povoar suas fazendas e afirmando que a "terra do Sertão era mui fértil, abundante e saudável", com pastos de boa qualidade para criação de gado. ${ }^{56}$

Com salva de trezentos tiros e toque dos instrumentos, a expedição foi encerrada na primavera de 1769, depois de 102 dias de jornada, na mesma fazenda onde iniciaram o percurso, localizada entre o arraial e a capela de Senhora da Oliveira ${ }^{(41)}$ e as vilas de São João(") e São José(2). O relato da "Notícia diária [...]" foi finalizado com a lista de novos entrantes e pedidos de sesmarias nos arraiais de Santa Anna de Bambohÿ, de Nossa Senhora da Conceição da Conquista do Campo Grande, no ribeirão das Araras, Andaia, até o rio do Picão e de Nossa Senhora do Livramento do Piuhÿ. ${ }^{57}$

Não tendo encontrado ouro em volume satisfatório, a utilidade pública dessa expedição foi reafirmada em seus relatórios por meio do destaque aos seus feitos, como: a promoção da lgreja Católica mediante a realização de batismos e a edificação de templos nos arraiais de Piuhÿ|(66) e Bambohÿ(70); a aplicação da justiça por intermédio de prisões e arbitragem de conflitos; a abertura de estrada de 49 léguas de comprimento desde o pouzo alegre ${ }^{(51)}$ até - Salitre ${ }^{(92)}$, com construção da ponte sobre o rio de São Francisco ${ }^{\mid 68)}$ (que apresentaria vantagem em relação ao caminho velho por ser livre dos pântanos 
e travessias em canoas, tornando assim "mais suave a entrada dos que quisessem povoar aqueles sertões"); a concessão de sesmarias em terras férteis, com campos para criação de gado na mesma região por onde se abriu passagem; a contribuição para a extinção dos quilombos do Campo Grande, "tão projodiciais, e tão nucivos"; a demarcação de dois novos arraiais na região além da serra da Marçella ${ }^{(r)}$ (o da Senhora da Conceição e o de Santa Maria de Cortona do Salitre). ${ }^{58}$ Esse conjunto de iniciativas tinha a finalidade declarada de "dilatar o domínio americano" da coroa portuguesa. ${ }^{59}$

\section{OS QUILOMBOS DO CAMPO GRANDE SEGUNDO A EXPEDIÇÃO DE 1769}

Os sete quilombos encontrados pela expedição de 1769, liderada por Ignacio Correya Pamplona, tiveram alguns aspectos registrados em seus relatórios escritos $^{60}$ e nos seis desenhos de implantações (Figuras 1 a b), sendo a localização de alguns deles pontuadas no mapa da região explorada (Mapa 1). Chamadas por seu autor de "mapas dos quilombos", ilustrações como essas, detalhando o interior dos povoados quilombolas setecentistas, são especialmente raras.

Analisando as narrativas, percebemos que os memorialistas estiveram pessoalmente no Ambrozio(74), Sambabaÿa(76) (ou Samambaia), Santos Fortes ${ }^{(90)}$ (também chamado de Corisco) e Catiga||(91) (ou Catiguá, esse sem desenho de implantação). Outros povoados quilombolas foram invadidos somente por uma das duas bandeiras da expedição - que ora se destacavam do grupo de Pamplona, ora se reencontravam com ele -, caso dos dois quilombos da bacia do rio da Perdição[a] e do Sam Gonçalo(79), retratados nos documentos com base nos esboços e informações apresentados pelos comandantes das bandeiras ou a partir de explicações dos próprios quilombolas capturados. Denunciados pelas fumaças avistadas ao longe pelas tropas, mas não encontrados pela expedição, outros quilombos tiveram indicada nos manuscritos sua região aproximada.

A partir dessas narrativas e ilustrações, podemos vislumbrar alguns aspectos dessas diferentes povoações, como meio geográfico de implantação, tipos de produção de alimentos e manufaturas, uso das construções, sistemas de defesa, organização social e relações entre núcleos quilombolas. 
61. Barbosa (1972, p. 31-53).

62. Holanda (1957, p. 38$46,136-142)$

\section{Roças, Pilões e Manufaturas}

Todos os quilombos encontrados pela expedição de 1769 eram próximos a cursos d'água que corriam em suas imediações ou atravessavam o interior dos povoados. Além disso, o Catiga|(9)1) contava também com fontes de água salgada (mineral importante na alimentação animal) que nasciam na paragem do Salitre ${ }^{(92)}$.

O quilombo Grande, também conhecido como Ambrozio, nome de um de seus líderes, foi um dos maiores e mais famosos da região. Possivelmente fundado na década de 1720, foi destroçado em 1746, mas ressurgiu nos arredores pouco depois e foi novamente destruído em 1759, tendo nos dois eventos muitas casas, paióis e roças arrasados pelas expedições. ${ }^{61}$ Quando registrado pela campanha de Pamplona, restavam apenas ruínas do quilombo do Ambrozio(74) (Figura 3). Dessa maneira, os expedicionários de 1769 não puderam verificar os usos das edificações dessa antiga povoação ou os tipos e locais de cultivo de alimentos. Por isso, tais informações inexistem nesses documentos.

Os demais quilombos apresentados nos relatórios de 1769 eram ativos até aquele momento. Todos contavam com roças, sendo apontadas plantações de milho, mandioca, algodão e hortas. Os cultivos eram beneficiados pelos próprios quilombolas. A produção de farinhas aparece nas narrativas e na ilustração da "Caza de piloens", no caso do Sam Gonçalo.

No Sambabaÿa (Figura 4) foi indicada a existência de um "Cortume de Couros", revelando que nesse quilombo dedicava-se à atividade de tratar as peles de animais (que podiam ser usadas na fabricação de calçados, recipientes para transporte ou mesmo para vestimentas e materiais para proteção contra flechas inimigas, como também era feito por índios e sertanistas). ${ }^{62}$ Não há registro da origem das peles, isto é, se vinham de animais criados pelos quilombolas ou eram fruto da caça.

A manufatura de panos de algodão ou outros produtos com tal fibra foi sublinhada nos quilombos do "chamado do Rio da Perdiçaõ" [sic] (Figura 2), "de hum dos braços da perdiçaõ" [sic] (Figura 1), de Sam Gonçalo (Figura 5) e dos Santos Fortes (Figura 6), por meio da identificação de "Caza de Thear" nos desenhos e nos relatos de confiscos pelas tropas dos panos de algodão feitos pelos calhambolas. A fabricação própria de ferramentas para cultivo ou armas em ferro foi indicada pela presença de uma "Caza e forge de ferreiro" no Sambabaÿa, e pelo conjunto de "Cazas de ferreiro" no Sam Gonçalo.

Pelos documentos da campanha bélica de 1769, percebemos que os quilombos encontrados não eram ajuntamentos provisórios com uns poucos indivíduos. 
Ao contrário, eram todos bem estruturados, com "ranchos", "modo de ali se conservarem" e com casas o bastante para comportar dezenas ou centenas de pessoas.

\section{Organização social, conexão entre quilombos, reedificação de povoados}

Ignoradas por essas tropas inimigas, a organização social do trabalho e a vida cotidiana dos quilombos não foram apresentadas nos documentos. A diversidade de arranjos sociopolíticos dessas povoações pode ser entrevista a partir das construções identificadas nas imagens, dos depoimentos extraídos dos quilombolas aprisionados e de outros dados apresentados nas narrativas das expedições destruidoras.

As casas de ferreiro registradas no Sambabaÿa e no Sam Gonçalo indicam a capacidade de autossuficiência na produção de ferramentas, sendo possível inferir que os ferreiros estavam relacionados à ordenação política desses povoados quilombolas, pois eram figuras de liderança em culturas africanas, ${ }^{63}$ o que pode ter inspirado os arranjos sociais elaborados no contexto americano. O quilombo "chamado do Rio da perdiçaõ" contava com uma "Caza do Conselho", enquanto no Sambabaÿa havia uma "Caza de audiençia com aSentos" [sic] afastada das outras construções, localizada perto do curso d'água e da mata. No quilombo "de hum dos braços da perdiçaõ" foi identificada uma "Caza do Rey". Não sabemos exatamente que tipo de arranjos políticos quilombolas eram esses nos quais foram identificados reis e cortes nos documentos luso-americanos. É possível que alguns quilombos de fato tivessem lideranças entendidas como reis, visto que eram figuras usuais na África e Europa de então, ${ }^{64}$ além de as instituições monárquicas europeias se estenderem a suas colônias na América. Nos relatórios da campanha de 1769 não há informações sobre as organizações sociopolíticas dos quilombos do Catigal, do Santos Fortes ou do antigo Ambrozio.

Em ambos os quilombos do rio da Perdição há o desenho de uma cruz entre dois totens em "i" que, provavelmente, representam a presença de cemitérios no interior desses povoados. Implantados no centro do quilombo, junto às casas do rei e do conselho, esses cemitérios podiam estar relacionados a práticas de reverência aos ancestrais e à identidade de linhagem ${ }^{65}$ dos quilombolas, com a manutenção dos restos mortais dos antepassados perto das habitações e dos locais de culto religioso.

Uma longa passagem do relatório dos mapas permite vislumbrar importantes detalhes sobre o funcionamento dos quilombos analisados, como a devoção a um santo católico, a reedificação de quilombos, a conexão entre povoados e a especialização de ao menos um deles como local para plantação de alimentos:
63. Em algumas culturas da África subsaariana o ícone do ferreiro era revestido de autoridade sociopolítica ou até mesmo religiosa. $\mathrm{O}$ conhecimento de técnicas de fundição de ferro para fabricar ferramentas foi fundamental para o domínio dos povos bantos sobre a África central equatoriana, onde as florestas tropicais concorriam com a fixação de populações e o cultivo de alimentos. Na África ocidental, a extração do ouro e seu uso em pó para comércio de longa distância com outros povos era uma prática secular. O tráfico humano da África para as colônias portuguesas na América fez com que as culturas africanas influenciassem as regiões que receberam essas pessoas (GOMES, 2005, p. 358-395; KI-ZERBO, 1972, p. 29-32, 122-126, 139-141, 172-416; M'BOKOLO, 2009, p. 11-14, 49-53, 168-180; RUSSELL-WOOD, 2005, p. 101).

64. Martins (2008, p. $178-$ 187).

65. Entre os Iorubás, os ancestrais mortos eram enterrados nos pátios junto às moradias das famílias extensas e tais cemitérios privados se ligavam à identidade de sua linhagem. Nos terreiros de candomblé brasileiros, espaços de celebrações religiosas e reunião comunitária de matriz africana, também há reverência aos antepassados. (CUNHA, 1985, p. 45; SILVA, 2005, p. 63-65). 
66. [Encontrando Quilombos]. Transcrição e edição por Maria Filgueiras Gonçalves. Anais da Biblioteca Nacional, Rio de Janeiro, v. 108, 1988, p. 102).

67. O "petipé" ou "petipê" era uma escala gráfica usual na época. A medida adotada podia ser gravada em régua de latão ou madeira para servir de instrumento para levantamento em campo e, depois, para transposição dessas medidas para os mapas (BUENO, 2007, p. 38-40).
No dia 29 [...] sobimos a Serra de São Rafael [...] por onde Conhecemos que ia a picada velha de Goiases [...]. Do chapadão desta Serra vimos o lugar do Quilombo de São Gonçalo ${ }^{79}[$, ] o qual o comandante de uma das Bandeiras[,] o Tenente José da Serra Caldeira[,] de repente topou e nele amarrou um Negro que ali estava e os mais fogiram para onde novamente estavam outros camaradas estabelecendo outro novo Quilombo para breve mente se modarem todos, e ali só estavam alguns que se ocupavam em fazer farinhas para os mais[,] as quais o mesmo Comandante confiscou junto com vários trastes e panos de Algudões feito[s] ricamente pelos mesmos Negros, do qual por me dar tão fiel cópia fiz o presente Mapa para ademiração do munto que eles trabalham para Si.

Indaguei a rezão por que se nomeava Quilombo de São Gonçalo, e achei que os primeiros povoadores que tinham estado em outro Quilombo nas Cabeceiras do Rio das onze mil virgens donde saíram por padecerem aí uma grande Epidimia que os obrigou a devota mente fazerem ofericimento ao dito Santo a ereção de um novo Quilombo com o título de São Gonçalo [...].

No dia 30 fomos seguindo o rumo da dita picada velha que em partes nos aparecia e tendo andado Légua e meia ${ }^{89}$ topamos um corgo... em que o dito Senhor deu o nome de Santa Iria [...], o qual passamos e seguindo o mesmo Rumo chegamos de Frote do Quilombo de Santos Fortes $\mathrm{em}^{90}$ [,] distante pouco menos de uma Légua[,] onde Largamos a dita picada e fomos ao dito Quilombo para ver se achávamos alguns Negros dos que tinham fogidos do Quilombo da Samambaia[,] e neste Lugar os destroçou e saquiou grande quantidade de panos de Algudões e feitos nos dito Quilombo e outros mais Ro[u]bos que eles tinham feito[,] ali nos demoramos de se plantar a Roça que eles tinham queimado por Cuja rezão tive tempo de tirar o Mapa do dito Quilombo,[...] e como prometi das maior Individuação do Quilombo da Samambaia[,] digo que estes Negros estavam em um Quilombo em ums dos Braços da perdição[,] ao pé de outro Quilombo na mesma perdição [...], e daqui se retiraram o ano passado a fazerem roça na Samambaia por the ficar mais perto para conduzirem o seu Mantimento e daí melhor estabalecer; Este Quilombo, cuja notícia so[u]bemos por um Negro que o dito José Cardoso amarrou[,] vindo-se retirando da Samambaia para este que antigamente se chamava do Corisco outro que aqui houve[,] de que ainda se vê vestijos[,] por Cair um raio a[r]Redado dele meia Légua, Lugar por onde nos passamos e se vê ainda os regos que abriu a Terra. ${ }^{66}$

Quanto ao Sam Gonçalo, além da constatação de algum tipo de devoção pelos quilombolas ao santo católico, para o qual foi oferecida a ereção desse quilombo, é interessante a transposição desse povoado para outra região, descrita nesse excerto. Enquanto os "primeiros povoadores" estavam estabelecidos perto das nascentes do rio das Honze mil virgens ${ }^{[81]}$, junto à serra das Mangabas ${ }^{[1]}$, devido a uma epidemia uma nova geração de moradores (que podiam ser seus descendentes ou novos integrantes agregados posteriormente) refez o quilombo em uma área de campinas ${ }^{[r]}$ no vale entre as serras de São Rafae ${ }^{[m w]}$ e Santa Fế ${ }^{[w]}$. Na narrativa transparece que a mudança de local de habitação não extinguiu a relação de continuidade com o povoamento original. Tomando medidas a partir do petipéb7 indicado no mapa, pode-se estimar a distância, em linha reta, entre ambos os quilombos, em aproximadamente doze léguas (percurso que não poderia 
ser transposto em menos de dois dias de marcha por uma tropa em terreno livre de dificuldades advindas do relevo ou hidrografia).

Chama a atenção a conexão apontada entre os quilombos de "hum dos braços da perdiçaõ" [sic] e Sambabaÿa. Segundo a descrição, os habitantes do quilombo próximo a um afluente do rio da Perdição[a] foram para o Sambabaÿa ${ }^{(76)}$ (distantes aproximadamente sete léguas), pelo fato de o local ser mais apropriado para fazer roça e, portanto, melhor para ali se estabelecerem. No entanto, o dito quilombo de "hum dos braços da perdiçaõ" não foi esvaziado para fundação do Sambabaÿa, mas continuava ativo até a invasão da bandeira de 1769, ou seja, os dois povoados existiam simultaneamente.

A proximidade dos quilombos da Sambabaÿa(76) e do antigo Ambrozio(74) (a menos de duas léguas de distância), ambos na subida da serra das Mangabas ${ }^{[\mathrm{H}]}$, também é motivo de nota. Como visto, o Ambrozio, ou quilombo Grande, foi erguido e reerguido nessas partes, permanecendo na zona por ao menos quatro décadas e sendo extinto em 1759 pela expedição comandada por Bartolomeu Bueno do Prado. No entanto, dez anos depois outro quilombo foi encontrado por Pamplona na mesma região, dessa vez nomeado pelos expedicionários como Sambabaÿa. Assim, a área onde estavam o Sambabaÿa e o Ambrozio se mostrava particularmente interessante para a implantação de povoações quilombolas. registro de criação do Sambabaÿa por habitantes de quilombo junto ao rio da Perdição, que iam até tal local (distante mais de um dia de marcha) para lá "fazerem roça" e "melhor estabalecer", evidencia que essas terras eram especialmente adequadas ao cultivo. Esse quilombo talvez pudesse servir de pouso para fazerem o plantio e a colheita, para então "conduzirem o seu Mantimento" para outros povoados que fizessem parte da mesma comunidade. Outra possibilidade é que os quilombolas conduzissem tal mantimento para o comércio clandestino com luso-americanos, opção menos provável, já que era restrita a presença de súditos lusitanos na região naquele momento.

A ligação do Sambabaÿa ${ }^{(76)}$ com o Santos Fortes ${ }^{(90)}$ (afastados cerca de treze léguas um do outrol foi ratificada pela prisão de um quilombola que ia do primeiro para o segundo, sendo que a expedição conseguiu chegar ao Santos Fortes a partir da informação extraída desse prisioneiro. Esse trânsito de habitantes entre os quilombos evidencia que havia relações entre tais povoações. $\bigcirc$ quilombo dos Santos Fortes, cujo acesso ocorria em meio a matas fechadas, estava implantado em local próximo ao antigo quilombo do Corisco, cujo local teria sido atingido por um raio que abriu um vão na terra. Não foi informado se os habitantes do antigo Corisco e do Santos Fortes eram os mesmos ou se a nova povoação foi fundada por pessoas de outras proveniências, que escolheram o local por vantagens geográficas. 
68. [Encontrando Quilombos]. Transcrição e edição por Maria Filgueiras Gonçalves. Anais da Biblioteca Nacional, Rio de Janeiro, v. 108,1988 , p. 75 .
A reedificação de um quilombo novo no mesmo local de um anterior inativo aparece também no relato sobre o Catiga|(91). Em certa paragem

esteve já muntos anos e há poucos se tornou a retificar um quilombo chamado o Catiguá, de mais de cento e cinquenta jiraus, sendo certo que foi quilombo de munta força e de munto poder, o que claramente se evidenceia, porque havendo nestas paragens muntos matos, os mais próximos ao lugar do mesmo quilombo todos estão destruídos e safados das muntas e repetidas plantas que os Negros ali fizeram [...]. ${ }^{68}$

Segundo a descrição, esse povoado, que no passado contava com mais de uma centena e meia de construções /que deviam ser usadas para habitações ou para beneficiamento das produções, organização política local e demais usos comunitários, tomando por modelo os quilombos vizinhos representados nos relatórios), tinha como evidência de sua antiga "força" e "poder" a dimensão da clareira aberta em meio à mata fechada (feito que exigia grande dedicação de trabalho, assim como disponibilidade de ferramentas para derrubar árvores e demais vegetação). Esse espaço era desmatado para o plantio de roças e instalação das construções do quilombo.

Próximo à serra de São Rafael[mw], junto ao ribeirão do Salitre, o povoado do Catigal|(91) estava localizado a pouco mais de uma légua da mata do Salitre ${ }^{(92),}$ onde as fontes de água salgada atraíam animais, de forma que a caça era farta. Tendo a primeira povoação sido extinta anteriormente, talvez devido ao ataque de tropas inimigas, o quilombo foi novamente edificado sobre o mesmo espaço. No novo Catigal os quilombolas fizeram roças, cujos restos da colheita de milho foram apropriados pelas tropas de 1769. A preferência desse sítio para ereção do quilombo devia estar relacionada à disponibilidade de recursos naturais favoráveis à manutenção de povoados.

\section{Fortalezas e mirantes}

Como recurso para sua defesa, esses quilombos estavam implantados nos arredores de morros, que eram usados para avistar os inimigos ao longe. Apenas em duas povoações não foram registradas "espias" nos relatórios. Ainda assim, também nelas os quilombolas souberam com antecedência da chegada dos inimigos e fugiram.

As ruínas do quilombo do Ambrozio tinham estrutura de fortaleza, como podemos ver em seu desenho de implantação (Figura 3). Encerrando o centro 
habitável por todos os lados havia uma trincheira com guaritas que, por sua vez, era envolta em três faces por um fosso com 15 palmos de largura laproximadamente $3,40 \mathrm{~m}$ ) crivado de estrepes, ${ }^{69}$ enquanto o trecho oeste ${ }^{70}$ era protegido por um brejo com buracos e estrepes. A partir da proporção gráfica em petipé inserida na legenda, podemos considerar que a trincheira teria cerca de $100 \times 100 \mathrm{~m}$, encerrando área de 10 mil m². $\bigcirc$ núcleo fortificado do Ambrozio, limitado pelo fosso, ocuparia aproximadamente $125 \times 125 \mathrm{~m}$, com área total de $15.625 \mathrm{~m}^{2}$. Essa estimativa de área por meio do petipé é coerente com as informações do levantamento arqueológico do Ambrozio, que encontrou os vestígios do fosso em forma de ferradura limitando uma área de aproximadamente $15 \mathrm{mil} \mathrm{m}^{2}{ }^{71} \bigcirc$ conjunto era rodeado por restingas de matos com vertentes de água e por um campo limpo na face leste, com um morro próximo da povoação que servia como mirante para espia.

A construção de fortificações também é verificada no Sam Gonçalo (Figura 5). De acordo com o desenhista da campanha de Pamplona, o espaço habitável desse quilombo era protegido por uma larga trincheira com 10 palmos de altura laproximadamente 2,30 m) que o circundava integralmente. Essa trincheira era atravessada por uma entrada com dois fojos (buracos), por dois buracos para fuga e por uma saída com estrepes apontados para o exterior da povoação. Tais dispositivos, aparentemente, inviabilizavam o acesso ao quilombo a cavalo ou por tropas de pedestres em velocidade. $\bigcirc$ Sam Gonçalo tinha matas ao redor da trincheira, estando situado no mapa da expedição em região de campinas, no vale entre duas serras.

Uma vez que o Ambrozio e o Sam Gonçalo não ficavam em meio à mata fechada, mas rodeados por restingas de matos e campinas, as estruturas fortificadas e a utilização de morros próximos da povoação como mirantes para espia eram fundamentais para a preservação do povoado e de seus moradores. Nos outros quatro quilombos encontrados pela campanha não foram representadas construções de estruturas fortificadas.

Nos documentos da expedição de 1769 não estão descritas reações armadas dos quilombolas contra as tropas. Sobre os dois quilombos na bacia do rio da Perdição, os relatórios falam de mortos (cujo número não foi informado) e de um prisioneiro, tendo os demais fugido. No Sambabaÿa, no Santos Fortes e no Catigal ocorreram fugas; no Sam Gonçalo a maioria fugiu, e alguns foram capturados de surpresa fazendo farinha. Os expedicionários acreditavam que os calhambolas se refugiavam em outros quilombos próximos. É notável que, apesar da provável superioridade de armamentos da campanha de Pamplona, foram destacados nas narrativas o perigo e o temor das tropas quanto ao enfrentamento contra os "Negros".
69. Estrepes são pontaletes agudos fincados ao solo para dificultar o acesso dos inimigos aos espaços por eles protegidos. Nesse caso, provavelmente eram feitos de madeira.

70. O documento teve a rosa dos ventos destacada, devido à reação do papel à tinta ferrogálica. No entanto, as marcas de migração do pigmento para a outra folha do documento permitem deduzir sua posição original. Parte do centro do desenho foi omitida pela encadernação. Deduzimos a continuidade do fosso (item 1) nesse trecho pela curvatura no canto superior esquerdo das linhas paralelas que o delimitam e pela presença do número "6" (Distançia entre foço, e trinxera com estrepes) no limite visível da folha.

71. Cardoso e Guimarães (2001, p. 35-58). 
72. [Encontrando Quilombos]. Transcrição e edição por Maria Filgueiras Gonçalves. Anais da Biblioteca Nacional, Rio de Janeiro, v. 108,1988 , p. $58-60,64$.
O desconhecimento da região pelos luso-americanos e a dificuldade de acesso a alguns quilombos, situados em meio a matas fechadas, favoreciam a permanência desses povoados quilombolas na região. Mesmo nas áreas onde as fumaças indicavam a existências de quilombos ${ }^{185,871}$, nem sempre as tropas destruidoras tiveram sucesso em encontrá-los. Com o encerramento da campanha de 1769, ainda se mantiveram alguns quilombos nas imediações do novo caminho aberto pela expedição.

\section{População quilombola}

Nos diários da campanha os habitantes dos quilombos foram chamados de "Negros", "negros aquilombados" ou "calhambolas". Nos mesmos textos aqueles que estavam submetidos aos agentes lusitanos também são chamados de "Negros", "escravo" ou "bom preto". A divisão da sociedade local foi evidenciada em certo evento no qual Pamplona foi procurado para resolver questões sobre terras e justiça, quando o relator descreveu a presença de pessoas "brancas", mais "pardagem" e "Negraria", em que os últimos provavelmente eram escravizados dos primeiros. ${ }^{72}$ Sendo assim, nesse relato, "Negro" é uma categoria relacionada à cor de pele e também à passagem pela condição de escravizado.

Visto que nas minas setecentistas predominavam os africanos e seus descendentes na condição de escravizados, ao se referirem aos quilombolas como "Negros" os memorialistas estavam presumindo que eles eram pretos de ascendência africana fugitivos do cativeiro. No entanto, tal hipótese dos expedicionários nem sempre era confirmada pelos combatentes, já que a maioria dos quilombolas fugia antes da chegada das tropas. Na campanha de 1769, o contato direto entre esses grupos rivais ocorreu durante o confronto junto ao rio da Perdição, quando mataram os quilombolas, e por meio de uns poucos prisioneiros que tiveram que acompanhar a expedição. Como visto anteriormente, é provável que a população quilombola do Campo Grande fosse constituída majoritariamente por africanos fugitivos do cativeiro, misturados com indígenas que ainda viviam na região e, mais raramente, com algum luso-americano foragido.

\section{Aspectos gerais dos quilombos retratados pela expedição de 1769}

Vemos que os sete quilombos documentados pela campanha de 1769 apresentavam configurações bem distintas, uns em matas fechadas, outros em campinas, alguns fortificados, outros contando com recursos do ambiente para sua defesa, cada 
um com seu conjunto de construções que apontam diferentes organizações sociopolíticas e tipos de produção. Todos tinham em comum os cursos d'água, eram ao menos parcialmente envoltos por matas e tinham áreas para cultivo de roças. ${ }^{73}$

registro de "roças", "pilões" e manufaturas nesses povoados quilombolas indica alguma estabilidade desses ajuntamentos no local, assim como sua capacidade de suprir a própria demanda de subsistência. Ainda que pudessem ocorrer ataques de quilombolas contra os luso-americanos (em fazendas e estradas), não parece que tais atividades estivessem relacionadas à subsistência dos quilombos, visto que eles tinham meios próprios de manutenção.

É provável que alguns desses quilombos implantados em diferentes locais cumprissem funções especializadas, como fornecimento de alimentos e organização sociopolítica (em torno de reis, conselhos, assembleias ou outros tipos de lideranças) ou religiosa (onde talvez se incluíssem os cemitérios), compondo uma comunidade maior, cujos integrantes estavam dispersos em diferentes aglomerações constituintes de uma mesma rede quilombola. ${ }^{74}$

\section{MAPA ATUAL COM LOCALIZAÇÃO GEOGRÁFICA DOS POVOADOS}

Procurando uma apresentação espacial mais ampla e legível, transferi para um mapa atual certas informações oferecidas pelos documentos sertanistas. Pela facilidade de acesso, confiabilidade e qualidade dos materiais, adotei como base de trabalho os mapas físicos fornecidos pelo Instituto Brasileiro de Geografia e Estatística (IBGE). ${ }^{75}$

Confrontando o mapa histórico (Mapa 1) com a base cartográfica atual, a partir dos cursos d'água, serras, povoados e outros elementos que ainda hoje são conhecidos por nomes similares, é possível ter uma boa ideia das regiões onde estariam localizados os quilombos representados, o que permitiu construir um mapa atualizado (Mapa 2).

A partir desse mapa recente observamos que a região abordada fica em uma zona de planalto abundantemente irrigada. Os quilombos do Ambrozio ${ }^{(74)}$, Sambabaÿa ${ }^{(76)}$ e Catiga|(91) estavam implantados na cadeia de serras entre os rios Quebra-Anzol, Paranaíba e São Francisco (nomes atuais). $\bigcirc$ Sam Gonçalo(79) e o Santos Fortes ${ }^{(90)}$ estavam no vale do rio Quebra-Anzol. Esses cinco povoados ficavam junto a cursos d'água que integram a bacia do Paranaíba. Os locais onde foram avistadas fumaças ${ }^{185,87)}$, sem que a expedição tenha encontrado as
73. A relação entre os quilombos e as características geográficas, físicas (relevo, clima, solos, hidrografia e vegetação) e humanas (população, tipo de povoamento, integração entre grupos, distribuição da população no espaço) de seus territórios de implantação é analisada por Andrade (2001, p. 75-86)

74. Os indícios de uma rede quilombola no Campo Grande que podem ser verificados nesses e em outros documentos do mesmo período foram analisados detalhadamente na dissertação de mestrado que originou este artigo (FREIRE, 2020, p. 39-169).

75. IBGE. Cartas e mapas. Disponível em: $<$ https://bit. ly/2CawxR5>. Acesso em: 9 abr. 2021. 
habitações, ficavam junto à região de nascentes do rio Paranaíba. Já os dois quilombos do rio da Perdição(a), curso d'água que se junta ao rio de São Francisco[k], não tiveram suas posições identificadas no mapa da jornada, sendo informado apenas que ficavam junto à serra da Marçella[r].

Como vimos, todos os quilombos registrados pela expedição de 1769 eram irrigados por cursos d'água, e apenas os dois povoados do rio da Perdição[a], ao pé da serra da Marçella, estavam em região desfavorável ao cultivo de alimentos. Os demais quilombos ocupavam áreas propícias à agricultura: junto a restingas (caso do Ambrozio e seu vizinho, Sambabaÿa), em meio às campinas (Sam Gonçalo) ou a matas (Santos Fortes e Catigal). Entre esses, apenas o Sam Gonçalo não foi aproveitado pelas tropas de Pamplona para plantio destinado ao abastecimento de futuras expedições luso-brasileiras, uma vez que se localizava longe da estrada que estavam abrindo para novo povoamento subordinado ao Estado português.
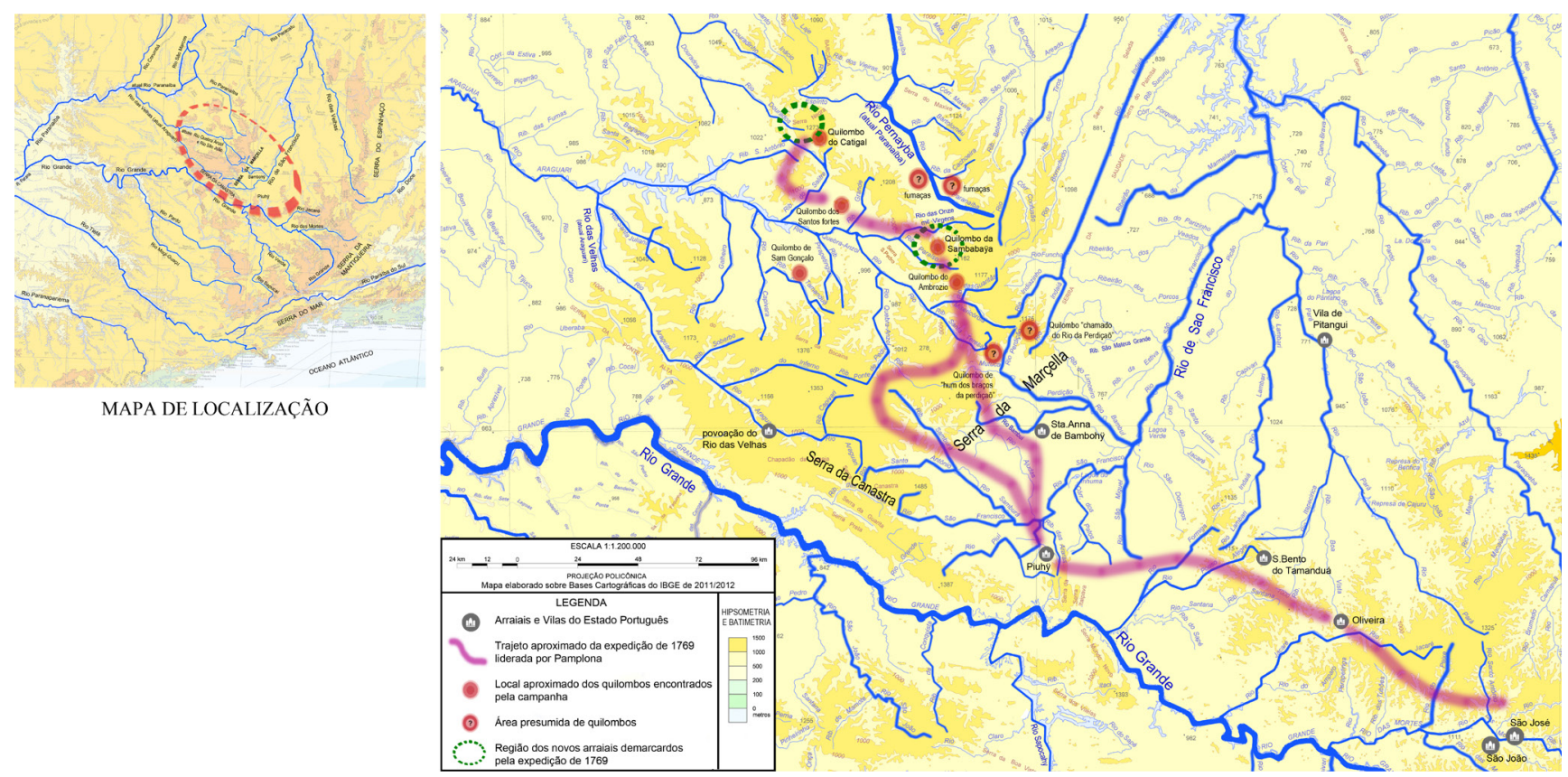

Mapa 2 - Releitura do mapa da expedição de 1769 com a localização aproximada dos quilombos e dos novos arraiais demarcados por Pamplona, sobre base cartográfica do IBGE editada. 
POVOAMENTOS CONCORRENTES NAS BORDAS DO OURO

As manchas de povoamentos subordinados ao Estado português na região do Alto São Francisco e Alto Paranaíba eram restritas. Os relatórios da expedição de Pamplona de 1769 definem os limites da colonização luso-americana ao longo do caminho que saía das vilas de São José(2) (atual Tiradentes) e São João(1) rumo a Paracatu. De acordo com esses memoriais, a área entre o rio Grande ${ }^{(34)}$ e o rio Jacaré[b] já era povoada naquele momento. Porém, passadas somente cinco léguas do arraial de Nossa Senhora da Oliveira ${ }^{(41)}$, indo para o Piuhÿ(66) e Bambohÿ(70), o povoamento era escasso e com parco alcance do poder eclesiástico. A serra da Marçella ${ }^{[r]}$ era marco de fronteira do "Sertão", a partir de onde não morava mais ninguém além dos "negros calhambolas".

A parte da região do Campo Grande explorada por Pamplona em 1769 situava-se em meio a uma cadeia de serras conhecidas hoje por Canastra, Bocaina, Negra, Zagaia e outros nomes (tendo a denominação "Marçella" caído em desuso), que concentram nascentes da bacia do Paranaíba e São Francisco (Mapa 2). A presença abundante de quilombos nessas partes foi reafirmada a todo tempo nos documentos da expedição.

Temendo o confronto com os calhambolas, os escreventes se referiram ao sertão do Campo Grande como "infestado por negros", ao mesmo tempo que divulgaram a expedição de Pamplona como promotora do "povoamento" naqueles espaços. Com tal discurso, justificava-se o extermínio dessas populações não integrantes da ordem colonial portuguesa. Para viabilizar a nova estrutura colonial subordinada ao governo da capitania de Minas Gerais naquele sertão, as tropas de 1769 abriram uma estrada e montaram pousos para os viajantes.

\section{Abertura de estradas e estabelecimento de ranchos para tropas}

Uma tentativa anterior de ocupação desse sertão por agentes da coroa lusitana foi evidenciada nos relatórios pela reminiscência da "Picada velha de Goiases, feita por Urbano Couto", que passava próxima do quilombo dos Santos Fortes ${ }^{(90)}$. Porém, desse caminho só restavam vestígios, não tendo vingado seu uso naquelas partes. ${ }^{76}$

A estrada nova aberta no sertão do Campo Grande pelas tropas de Pamplona conectava os povoados do Ambrozio(74), da Sambabaÿa(76), do Santos Fortes $^{(90)}$ e do Catiga|(1911. Para facilitar a entrada de outras campanhas através desse acesso, a expedição cultivou víveres ao longo do caminho. ${ }^{77}$ Como visto,
76. [Encontrando Quilombos]. Transcrição e edição por Maria Filgueiras Gonçalves. Anais da Biblioteca Nacional, Rio de Janeiro, v. 108,1988 , p. 96-103.

77. O cultivo de alimentos por tropas pioneiras para facilitar a exploração de novas áreas de conquista era uma prática usual entre bandeirantes paulistas (FONSECA, 2011, p. 61). 
78. Guimarães, op. cit., p. 46; Souza (2004, p. 47-48).

79. [Encontrando Quilombos]. Transcrição e edição por Maria Filgueiras Gonçalves. Anais da Biblioteca Nacional, Rio de Janeiro, v. 108,1988 , p. 64 .

80. Fridman (1999, p. 55-82).

81. Guimarães, op. cit., p. 90-97, 279-280.

82. O trabalho manual era considerado uma condição degradante, impedindo que indivíduos de ofícios mecânicos, inclusive jornaleiros e lavradores, recebessem nobilitações (SILVA, 2007, p. 191-219). essas roças não foram feitas em qualquer parte, mas sobre as terras dos quilombos, uma vez que os quilombolas já tinham selecionado os locais mais adequados e preparado o solo para o cultivo. Algumas variedades de vegetais plantadas pelas tropas coincidiam com as cultivadas pelos calhambolas, como milho, mandioca e algodão. Ou seja, os quilombos atravessados pela nova estrada e transformados em ranchos para o descanso e abastecimento dos entrantes luso-americanos se tornaram base da estrutura de ocupação portuguesa.

Enquanto os quilombolas obtinham suas liberdades e suas terras à revelia do Estado português, ou seja, de maneira instável, a colonização luso-brasileira era amparada pela organização estatal à qual estava submetida, cujos aparatos bélicos e institucionais facilitavam seu estabelecimento no local de forma perene.

\section{Acesso à terra}

As atividades econômicas tributárias do Estado colonial português eram fundadas sobre a escravidão, tanto como mão de obra quanto como critério de distribuição de terras. As concessões de datas para extração de ouro e minerais preciosos, assim como de sesmarias para cultivo e criação de gado, estavam condicionadas ao número de escravizados que o proponente possuía, ${ }^{78}$ fato que foi reforçado no discurso de Pamplona. ${ }^{79}$

Desde meados do século XVIII, para obter um título formal do direito de exploração das glebas concedido pela coroa de Bragança era necessário que os requerentes comprovassem sua capacidade de produção, mediante a quantidade de escravizados possuídos e os meios de manter seu domínio pela força de armas. As terras desbravadas que não tivessem ocupação e produtividade suficientes seriam consideradas devolutas, devendo ser repassadas a quem tivesse meios de fazê-lo. ${ }^{80}$

A concessão de sesmarias era restrita aos nascidos livres, sendo vedada aos escravizados e alforriados, mesmo que esses "negros" tivessem se dedicado à extinção de quilombos em nome da coroa de Bragança. ${ }^{81}$ Dessa maneira, apesar de os escravizados constituírem parte expressiva das tropas expedicionárias (sendo compulsoriamente enviados por seus proprietários para as entradas a fim de abrirem picadas, construir pontes e pousos, fazer roças, caçar animais para alimentação do grupo e tocar instrumentos musicais), as retribuições da coroa em terras ou títulos ${ }^{82}$ eram bloqueadas a esses indivíduos. 
A apropriação de novas terras para exploração agropecuária por meio do trabalho de escravizados, com confirmação da posse mediante a concessão de sesmarias, foi um dos frutos das investidas de Pamplona no Campo Grande. A Coroa, como retribuição pela realização dessa e de outras campanhas de conquista no Alto São Francisco e Alto Paranaíba, tornou Ignacio Correya Pamplona um dos maiores proprietários de terras da região. Ele recebeu em seu nome e no de sua família a concessão de várias sesmarias, que mediam 3 léguas de largura por 3 de comprimento, totalizando 9 léguas em quadra. ${ }^{83}$

Considerando a medida usual na cartografia da América portuguesa, na qual 1 légua equivale a $6,52 \mathrm{~km},{ }^{84}$ cada uma dessas sesmarias teria aproximadamente 38.283 hectares, ou $382,83 \mathrm{~km}^{2}$. Para se ter ideia da magnitude dessas terras, em comparação com certas localidades da mesma região, ${ }^{85}$ caberiam apenas duas ou três sesmarias inteiras dentro dos atuais municípios de Piumhi, São Gotardo, Araxá, Bambuí, São João del Rei e ltapecerica (antiga São Bento do Tamanduá), ou 7,5 sesmarias em Patrocínio.

Dando sentido à apropriação do solo por meio da violência, a repartição das terras dos inimigos entre os súditos portugueses que se dedicaram a seu extermínio (que recebiam a concessão de grandes extensões de terras) foi uma prática comum naquele momento, sendo também constatada em outros documentos de conquista dos sertões americanos. ${ }^{86}$

\section{Arraiais luso-americanos sobre territórios quilombolas}

Os arraiais luso-americanos instalados em meio aos territórios que estavam em processo de apropriação serviam de instrumento de controle da população submetida àquela estrutura de poder. Depois de estabelecidos, funcionavam como postos avançados para novas frentes de conquista. ${ }^{87}$ Esse foi o objetivo declarado no discurso de Pamplona ao demarcar os dois novos povoados durante a campanha de 1769 (ver tracejado em verde no Mapa 1). - arraial de Santa Maria de Cortona do Salitre ${ }^{(93)}$ foi demarcado nas imediações do quilombo do Catiga|(91). Por sua vez, o arraial de Nossa Senhora da Conceição foi demarcado sobre o quilombo da Sambabaÿa(76), próximo à fazenda que Pamplona destinou para si mesmo, juntamente com o patrimônio para sua capela, cuja área era limitada pelo rio das Honze mil virgens ${ }^{(81)}$, quilombo do Ambrozio(74), córrego do Sacramento(77), córrego do Bom Jesus ${ }^{(75)}$ e pela serra de São Pedro de Alcantra ${ }^{(78)}{ }^{88}$
83. Barbosa (1971, p. 17-47, 124-125).

84. Santos (2007, p. 51-81). 85. IBGE (2010).

86. Santos (2010, p. 187-189), Freire (2020, p.155-158).

87. Santos (2010, p. 222-223).

88. [Encontrando Quilombos]. Transcrição e edição por Maria Filgueiras Gonçalves. Anais da Biblioteca Nacional, Rio de Janeiro, v. 108,1988 , p. $70,101$. 
89. Souza (1999, p. 111-137).

90. Fonseca, op. cit., p. 82123.

91. Cf. Santos (2010).

\section{Padroado régio e ocupação dos territórios americanos pelo Império lusitano}

Realizando batismos e missas musicadas, assassinando quilombolas, localizando, conhecendo, nomeando e reordenando os espaços antes dominados pelos "bárbaros", a expedição de Pamplona era promotora da "civilização" naqueles sertões. ${ }^{89} \mathrm{~A}$ campanha providenciou a construção de templos católicos, concedeu sesmarias e tomou posse das paragens para a capitania de Minas Gerais em nome do governador conde de Valadares, ações formalizadas por atos públicos.

O Estado colonial português era indissociável da lgreja Católica em razão do padroado régio, acordo no qual, em troca da promoção da fé católica no Novo Mundo, o recolhimento de impostos eclesiásticos era destinado à coroa de Bragança. ${ }^{90}$ Por esse motivo, nas terras que a expedição de 1769 buscava conquistar, foram erguidos templos, colocadas imagens religiosas, fincadas cruzes e demarcados patrimônios eclesiásticos junto aos arraiais. Esses símbolos institucionais assinalavam a conquista daqueles locais pelo poder monárquico católico, ao mesmo tempo que intentavam suprimir organizações religiosas e políticas pré-existentes, quilombolas ou indígenas.

Como já dito, com as disputas entre os reinados ibéricos por territórios na América do Sul no século XVIII, o reconhecimento da soberania ocorria por meio da ocupação efetiva do território. $\bigcirc$ processo de apropriação territorial passava pela conquista dos espaços mediante batalhas contra os habitantes indígenas ou quilombolas (com produção de esboços cartográficos e relatos de campo para reconhecimento dos espaços pelo Estado português), pela estruturação da ocupação por meio da abertura de caminhos, distribuição de sesmarias, estabelecimento de povoados e postos militares, instalação de templos católicos e, por fim, pela territorialização material e simbólica dos sertões, convertidos em espaço de domínio material e mental do Império lusitano.91

Sendo assim, ao estender a presença da lgreja Católica e da administração civil sobre o Campo Grande, viabilizar a ocupação desses espaços por súditos da Coroa lusitana e, ao fim da expedição, destinar ao governo da capitania relatórios com mapas e descrições cartográficas das terras conquistadas, a campanha militar capitaneada por Pamplona em 1769 estava alinhada com o projeto português de ampliação e afirmação de seus domínios.

A partir dos relatórios dessa expedição bélica no Campo Grande vemos que a estrutura colonial luso-brasileira nessa região foi feita por meio do estabelecimento de ranchos para pouso dos tropeiros, fazendas, patrimônios da Igreja e arraiais superpostos à rede quilombola ali estabelecida, dificultando o 
restabelecimento dos povoados quilombolas naqueles locais. Tal superposição da estrutura colonial lusitana era também uma forma de posse simbólica dos territórios quilombolas. A demolição, seguida da substituição dos quilombos pelo aparato de seus conquistadores, extinguia aqueles povoados quilombolas duas vezes: tanto as entidades físicas como a memória de suas existências, ocultando seus vestígios.

A apropriação dos quilombos por agentes portugueses para constituição de sua própria estrutura colonial parece ter sido uma prática corrente, verificada em outros mapas de exploração e conquista do Campo Grande setecentista. ${ }^{92}$ Ao percorrer os rastros deixados pelos seus carrascos, na análise dos documentos sertanistas da campanha de 1769, verificamos que os quilombos constituíram a base sobre a qual foi estruturada a ocupação portuguesa nessas partes do Alto São Francisco e Alto Paranaíba, podendo ser considerados pioneiros na formação da malha territorial da região.

\section{CONSIDERAÇÕES FINAIS}

A análise dos relatórios da expedição liderada por Pamplona em 1769 ajuda a compreender as características e critérios de estabelecimento de povoados por esses grupos antagônicos. Nesse momento de contato entre adversários e de extinção dos quilombos que, contraditoriamente, foram gerados os documentos que hoje oferecem um dos poucos vestígios a partir dos quais se pode vislumbrar a história dessas povoações.

O povoamento por quilombolas da região serrana onde nascem os rios São Francisco, Paranaíba e afluentes (distantes alguns dias de marcha de núcleos mineradores), estabeleceu-se durante a década de 1720 ou antes. Mesmo após diversas batalhas contra expedições militares do Estado lusitano, muitos quilombos permaneceram naquelas paragens ao longo do século XVIII, refazendo sucessivamente suas construções e roças nas imediações.

Implantados nas margens de cursos d'água, todos os quilombos analisados tinham roças e alguns contavam com fortificações, teares, curtume, cemitérios, casas de ferreiros, de rei, de conselho e de audiência. As relações entre diferentes quilombos, por meio do fluxo de habitantes e mesmo de alimentos, foram confirmadas pelos relatórios da expedição destruidora, sendo possível que esses povoados estivessem também interrelacionados em suas organizações sociopolíiticas. Dessa maneira, podemos pensar nesses povoados não só como unidades
92. Freire, op. cit., p. 41-60, 99-112, 151-158. 
93. Guimarães, op. cit., p. 104-128. autônomas, mas também como integrantes de uma ou mais redes quilombolas mais complexas, nas quais núcleos com diferentes atribuições funcionavam em conjunto.

Na visão dos agentes do Estado colonial português, suas expedições a um só tempo eliminavam a "infestação de negros" e viabilizavam o "povoamento dos sertões". Em outras palavras, ao mesmo tempo que essa ação era entendida como povoadora, a existência de habitantes bem estabelecidos na região (com produção própria de alimentos, tecidos, manufatura de ferro, entre outros) eram considerados uma praga indesejavelmente disseminada na região. Tais povoados eram tidos como prejudiciais à colonização luso-brasileira, uma vez que a ameaçavam, devido ao risco de assaltos nas estradas ou de perda de escravizados das fazendas e arraiais. ${ }^{93}$ Todavia, a insubordinação dos quilombos ao aparato institucional da monarquia portuguesa provavelmente estava entre os principais motivos de tal postura de extermínio adotada em relação aos povoados quilombolas.

Examinando tal episódio, no qual grupos rivais (com diferentes arranjos sociopolíticos culturais) se confrontaram pelo domínio dessa região do Campo Grande, podemos afirmar que os quilombos ali existentes foram usados como base de implantação da estrutura física destinada ao povoamento da área por súditos da coroa de Bragança. No entanto, a fundação sobre aquele sertão dessa nova povoação subordinada ao governo da capitania de Minas Gerais não se distinguia da colonização quilombola pré-existente, quer fosse pelo local de implantação dos ranchos para descanso das tropas, pelas espécies cultivadas nesses pousos, pelo trajeto do caminho novo (cujo traçado conectava alguns dos quilombos encontrados), ou mesmo pela escolha dos sítios para fundação de novos arraiais, patrimônios eclesiásticos e fazendas (que foram demarcados nas imediações dos quilombos ou sobre eles).

A estratégia adotada pela expedição de Pamplona de ocupação por sobreposição à rede quilombola também foi usada por outras campanhas militares naquele momento de expansão colonial portuguesa. A superposição do povoamento luso-americano sobre os quilombos do Campo Grande Itrocando uma população de rebeldes por outra de indivíduos subordinados às leis, costumes, religião e tributação da Coroa lusitana) tinha como sinalização da conquista ibérica a abertura de estradas, construção de marcos religiosos, e execução de rituais de posse de terras acompanhados por músicos e comitiva montada, entre outros.

As mortes e prisões de quilombolas executadas por agentes lusitanos, seguidas da implantação dessas estruturas e símbolos do Estado português, intentavam exterminar aquelas populações indesejadas pela Coroa, ao mesmo tempo que ocultavam a memória da existência desses povoados quilombolas. Todavia, alguns 
quilombos ressurgiam na região mesmo após as sucessivas destruições causadas pelas tropas do Estado português, cuja superioridade bélica, até aquele momento, não era grande o bastante para que suas investidas contra os quilombolas fossem isentas do temor e das dificuldades que alarmavam os expedicionários invasores.

Mantendo a proeminência na região do Alto São Francisco e do Alto Paranaíba ao longo de um século e, ainda que involuntariamente, tendo servido de base para a formação da malha territorial dessa zona, os quilombos setecentistas constituem parte indissociável de nossa história. 


\title{
REFERÊNCIAS
}

\author{
FONTES MANUSCRITAS
}

[Mapa da expedição de 1769 de Ignacio Correya Pamplona], [1769?]. Papel. 1 folha, $90 \times 43 \mathrm{~cm}$. Manuscrito. Português. Acervo da Fundação Biblioteca Nacional - Brasil, Coleção Ottoni, Arquivo Conde de Valadares, código: MS-575 (1), folha 245.

Quilonbo chamado do Rio da perdiçaõ, [1769?], Papel. 2 folhas. Manuscrito. Português. Acervo da Fundação Biblioteca Nacional - Brasil, Rio de Janeiro, coleção Ottoni, Arquivo Conde de Valadares, código: MS-575(1), folhas 258-259.

Quilonbo da Sambabaÿa, [1769?], Papel. 1 folha. Manuscrito. Português. Acervo da Fundação Biblioteca Nacional - Brasil, Rio de Janeiro, coleção Ottoni, Arquivo Conde de Valadares, código: MS-575(1), folha 243.

Quilonbo de hum dos braços da perdiçaõ, [1769?]. Papel. 2 folhas. Manuscrito. Português. Acervo da Fundação Biblioteca Nacional - Brasil, Rio de Janeiro, coleção Ottoni, Arquivo Conde de Valadares, código: MS-575(1), folhas 250-251.

Quilonbo de Sam Gonçalo, [1769?], Papel. 1 folha. Manuscrito. Português. Acervo da Fundação Biblioteca Nacional - Brasil, Rio de Janeiro, coleção Ottoni, Arquivo Conde de Valadares, código: MS-575(1), folha 244.

Quilonbo do Ambrozio, [1769?], Papel. 2 folhas. Manuscrito. Português. Acervo da Fundação Biblioteca Nacional - Brasil, Rio de Janeiro, coleção Ottoni, Arquivo Conde de Valadares, código: MS-575(1), folhas 238-239.

[Quilonbo] dos Santos fortes, [1769?], Papel. 1 folha. Manuscrito. Português. Acervo da Fundação Biblioteca Nacional - Brasil, Rio de Janeiro, coleção Ottoni, Arquivo Conde de Valadares, código: MS-575(1), folha 253.

FONTES IMPRESSAS

[Encontrando Quilombos]. Transcrição e edição por Maria Filgueiras Gonçalves. Anais da Biblioteca Nacional, Rio de Janeiro, v. 108, p. 47-113, 1988. Disponível em: <https://bit. ly/2PQo2RU>. Acesso em: 8 abr. 2021. 
AB'SÁBER, Aziz Nacib. Os domínios de natureza no Brasil: potencialidades paisagísticas. São Paulo: Ateliê, 2003.

ANDRADE, Manuel Correia de. Geografia do quilombo. In: MOURA, Clóvis (org.). Os quilombos na dinâmica social do Brasil. Maceió: Edufal, 2001. p. 75-86.

BARBOSA, Waldemar de Almeida. A decadência das Minas e a fuga da mineração. Belo Horizonte: Imprensa da Universidade Federal de Minas Gerais, 1971.

BARBOSA, Waldemar de Almeida. Negros e quilombos em Minas Gerais. Belo Horizonte: Selo Horizonte, 1972.

BUENO, Beatriz Piccolotto Siqueira. Desenhando o Brasil: o saber cartográfico dos cosmógrafos e engenheiros militares da Colônia e do Império. In: COSTA, Antônio Gilberto (org.). Roteiro prático de cartografia: da América portuguesa ao Brasil Império. Belo Horizonte: Editora UFMG, 2007. p. 29-49.

CARDOSO, Juliana; GUIMARÃES, Carlos Magno. Arqueologia do quilombo: arquitetura, alimentação e arte (Minas Gerais). In: MOURA, Clóvis (org.). Os quilombos na dinâmica social do Brasil. Maceió: Edufal, 2001. p. 35-58

COSTA, Antônio Gilberto (org.). Roteiro prático de cartografia: da América portuguesa ao Brasil Império. Belo Horizonte: Editora UFMG, 2007.

CUNHA, Marianno Carneiro da. Da senzala ao sobrado: arquitetura brasileira na Nigéria e República Popular do Benin. São Paulo: Nobel: Edusp, 1985.

FLEXOR, Maria Helena Ochi. Abreviaturas: manuscritos dos séculos XVI ao XIX. São Paulo: Arquivo do Estado, 1990.

FONSECA, Cláudia Damasceno. Espaço e poder nas Minas setecentistas. Belo Horizonte: Editora UFMG, 2011.

FREIRE, Karen Pessoa. Quilombos nas bordas do ouro: conflitos entre negros e agentes lusitanos pelo domínio do Campo Grande no século XVIII. 2020. Dissertação (Mestrado em Arquitetura e Urbanismo) - Faculdade de Arquitetura e Urbanismo da Universidade de São Paulo, São Paulo, 2020.

FRIDMAN, Fania. Donos do Rio em nome do rei: uma história fundiária da cidade do Rio de Janeiro. Rio de Janeiro: Jorge Zahar: Garamond, 1999. 
GOMES, Flávio dos Santos. A hidra e os pântanos: mocambos, quilombos e comunidades de fugitivos no Brasil (séculos XVII-XIX). São Paulo: Editora Unesp: Polis, 2005.

GOMES, Flávio dos Santos. Quilombos/remanescentes de quilombos. In: SCHWARCZ, Lilia Moritz; GOMES, Flávio dos Santos (orgs.). Dicionário da escravidão e liberdade: 50 textos críticos. São Paulo: Companhia das Letras, 2018. p. 367-373.

GUEDES, Max Justo. Introdução. In: COSTA, Antônio Gilberto (org.). Roteiro prático de cartografia: da América portuguesa ao Brasil Império. Belo Horizonte: Editora UFMG, 2007. p. 19-27.

GUIMARÃES, Carlos Magno. Quilombos, classes, estado e cotidiano: Minas Gerais, século XVIII. 1999. Tese (Doutorado em História) - Faculdade de Filosofia, Letras e Ciências Humanas, Universidade de São Paulo, São Paulo, 1999.

HOLANDA, Sérgio Buarque de. Caminhos e fronteiras. Rio de Janeiro: José Olympio, 1957.

KANTOR, Iris. Cartografia e diplomacia: usos geopolíticos da informação toponímica (17501850). Anais do Museu Paulista, São Paulo, v. 17, n. 2, p. 39-61, 2009. DOI: 10.1590/S010147142009000200004. Disponível em: <https://bit.ly/3bn3rwn>. Acesso em: 13 maio. 2021.

KI-ZERBO, Joseph. História da África negra I. Sintra: Publicações Europa-América, 1972.

MARTINS, Tarcísio José. Quilombo do Campo Grande: história de Minas que se devolve ao povo. Contagem: Santa Clara, 2008.

M'BOKOLO, Elikia. África negra: história e civilizações. Salvador: Edufba; São Paulo: Casa das Áfricas, 2009. v. 1.

MORAES, Fernanda Borges de. De arraiais, vilas e caminhos: a rede urbana das Minas coloniais. In: RESENDE, Maria Efigênia Lage de; VILLALTA, Luiz Carlos (orgs.). As Minas setecentistas. Belo Horizonte: Autêntica: Companhia do Tempo, 2007. v. 1, p. 55-85.

MOURA, Clóvis. Dicionário da escravidão negra no Brasil. São Paulo: Edusp, 2004.

RESENDE, Maria Efigênia Lage de. Itinerários e interditos na territorialização das Geraes. In: RESENDE, Maria Efigênia Lage de; VILLALTA, Luiz Carlos (orgs.). As Minas setecentistas. Belo Horizonte: Autêntica: Companhia do Tempo, 2007. v. 1, p. 25-53.

ROSS, Jurandyr Luciano Sanches. Os fundamentos da geografia da natureza. In: ROSS, Jurandyr Luciano Sanches (org.). Geografia do Brasil. São Paulo: Edusp, 2005. p. 32-65.

RUSSELL-WOOD, Anthony John. Escravos e libertos no Brasil colonial. Rio de Janeiro: Civilização Brasileira, 2005. 
SANTOS, Márcia Maria Duarte dos. Técnicas e elementos da cartografia da América portuguesa e do Brasil Império. In: COSTA, Antônio Gilberto (org.). Roteiro prático de cartografia: da América portuguesa ao Brasil Império. Belo Horizonte: Editora UFMG, 2007. p. 51-81.

SANTOS, Márcio Roberto Alves dos. Fronteiras do sertão baiano: 1640-1750. 2010. Tese (Doutorado em História) - Faculdade de Filosofia, Letras e Ciências Humanas, Universidade de São Paulo, São Paulo, 2010.

SILVA, Maria Beatriz Nizza da. A Coroa e a remuneração dos vassalos. In: RESENDE, Maria Efigênia Lage de; VILlAlTA, Luiz Carlos (orgs.). As Minas setecentistas. Belo Horizonte: Autêntica: Companhia do Tempo, 2007. v. 1, p. 191-219.

SILVA, Vagner Gonçalves. Candomblé e umbanda: caminhos da devoção brasileira. São Paulo: Selo Negro, 2005.

SOUZA, Laura de Mello e. Desclassificados do ouro: a pobreza mineira no século XVIII. Rio de Janeiro: Graal, 2004.

SOUZA, Laura de Mello e. Norma e conflito: aspectos da história de Minas no século XVIII. Belo Horizonte: Editora UFMG, 1999.

VENÂNCIO, Renato Pinto. Antes de Minas: fronteiras coloniais e populações indígenas. In: RESENDE, Maria Efigênia Lage de; VILLALTA, Luiz Carlos (orgs.). As Minas setecentistas. Belo Horizonte: Autêntica: Companhia do Tempo, 2007. v. 1, p. 87-102.

SITES

ARAÚJO, Roberto Jorge Chaves. Normas técnicas para transcrição e edição de documentos manuscritos, sistematizadas pela Comissão de Sistematização e Redação do II Encontro Nacional de Normatização Paleográfica. São Paulo: [s. n.], 1993. Disponível em: <https://bityli. com/77Cgt>. Acesso em: 9 abr. 2018.

IBGE. Cartas e mapas. Rio de Janeiro: IBGE, [201-?]. Disponível em: <https://bit.ly/2CawxR5>. Acesso em: 9 abr. 2021.

IBGE. Sinopse do censo demográfico 2010: Minas Gerais. Rio de Janeiro: IBGE, 2010. Disponível em: <https://bit.ly/38UULuA>. Acesso em: 9 abr. 2019.

Artigo apresentado em: 14/07/2020. Aprovado em: 12/03/2021. (c) BY 